\title{
1 Implications of a new chronology for the interpretation of the Middle and \\ 2 Later Stone Age of the upper Zambezi Valley.
}

Burrough SL, Thomas, DSG; Barham LS

\section{Abstract}

Single grain OSL dating has been used to produce new chronologies for three previously investigated sites in the northern Kalahari basin in western Zambia containing both Middle and Later Stone Age material (Phillipson 1975 a\&b). We find that Mode 3 (Middle Stone Age, MSA) assemblages in the Upper Zambezi Valley pre-date the Last Glacial Maximum. The chronology produced here is consistent with age estimates from a handful of dated sites within the wider Kalahari basin. The Mode 3 to Mode 5 (Later Stone Age, LSA) relationship at one site, Chavuma, is unlikely to be a continuous transition as previously thought. Instead we find a significant chronological hiatus between MSA material deposited at $66.5 \pm 9.9 \mathrm{ka}$ and LSA material deposited at $16.7 \pm 2.6 \mathrm{ka}$. We consider these dated archaeological finds within the context of current archaeological and palaeoenvironmental records for the region. The results demonstrate the highly variable climate history of the region and the limitations of the existing archaeological record for modelling human responses to habitat change.

\section{Introduction}

\subsection{Palaeolithic Archaeology in the Kalahari basin}

The southern African interior possesses a long record of human occupation (Barham, 2000; Burrough, 2016;) that, for the most part, remains poorly investigated. This is despite the richness of available sites reported in the middle of the twentieth century by Van Riet Lowe (1935), Clark (1950) Bond and Summers (1954) and others. Archaeological research has favoured sites that offer good organic preservation, with a strong focus on cave-sites along the South African coast (Backwell et al., 2014; Stewart et al., 2012;) (Figure 1). The interior Kalahari basin however possesses an abundance of Stone Age archaeological sites (see Burrough 2016 for an overview), albeit that many are in open air contexts. While these may often lack associated organic deposits, many are situated in landscape contexts that attest to extreme and repeated water deficits and surpluses (Burrough et al., 2009; Burrough and Thomas, 2013; Thomas et al., 2003; Thomas and Burrough, 2012) that have potentially 


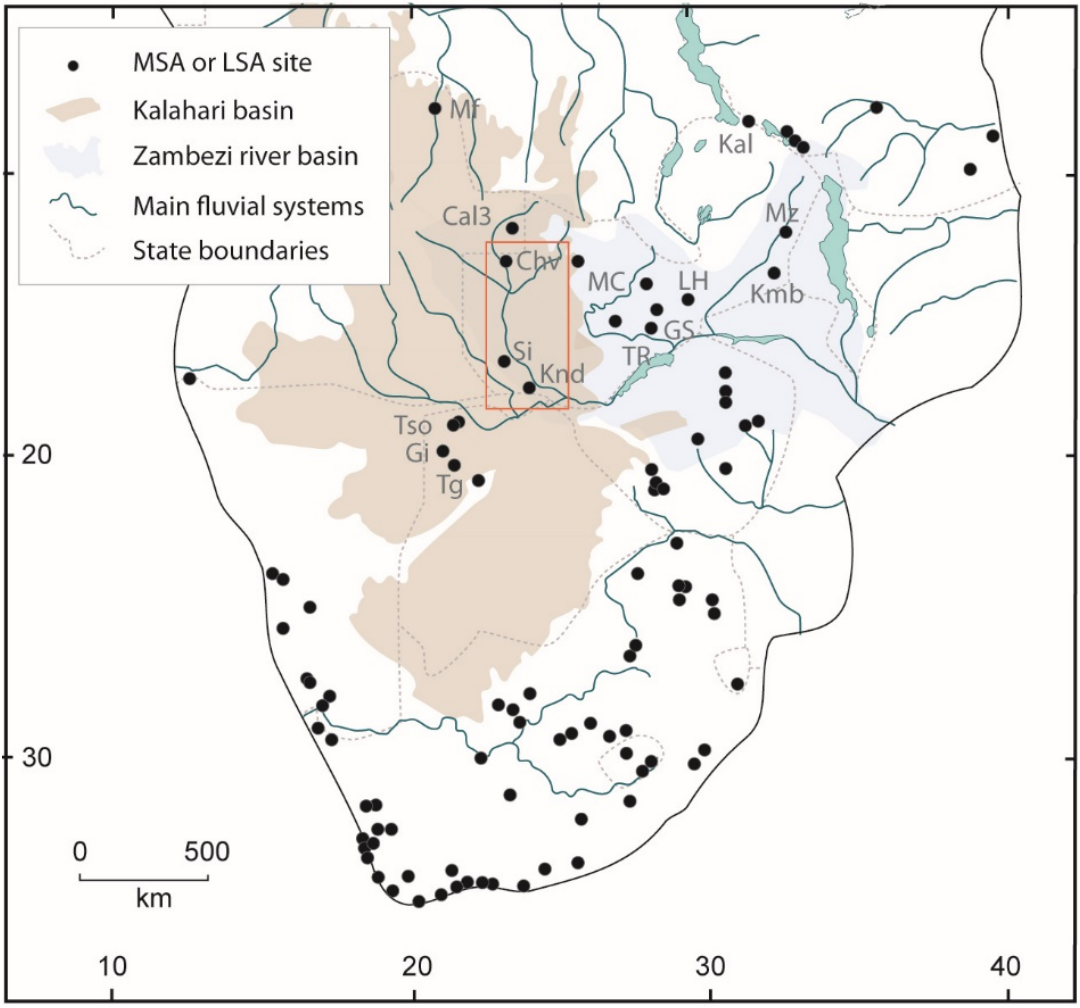

Figure 1: Published MSA and LSA archaeological site locations within southern Africa. The upper Zambezi region is marked with a red box. 1) Congo basin; 2) eastern Namib/western Kalahari rainfall record; 3) Megalake Makgadikgadi; 4) Tswaing Crater; 5) Zambezi Fan; 6) Lake Chilwa; 7) Lake Malawi; 8) Lake Tanganyika; Mf = Mufo; Cal3 = Calunda III; Chv = Chavuma; Si = Sioma M; Knd = Kandanda; Kal = Kalambo Falls; Mz = Manzi River; MC = Mumbwa Caves; GS=Gwisho Springs; TR = Twin Rivers; LH = Leopards Hill Cave; Kmb = Kalemba Rock Shelter; Tso = Tsodilo; Gi = \#Gi; Tg = Toteng.

Zambia, which includes the northeastern part of the Kalahari basin, provides key evidence from the Zambezi Valley (Clark, 1950) and high plateau (Clark, 2001; Barham, 2000) that demonstrate marked changes in the content and periodicity of occupation, with gaps in the record tentatively related to records of palaeoenvironmental change (Barham, 2001). Important themes to have emerged include the potential significance of fluvial systems as refugia during regionally dry conditions in the Pleistocene (Avery, 2003; Barham, 2001;). There are however very few chronologically constrained sites (particularly in association with river systems) to test whether this is a real pattern or an artefact of research to date. Nevertheless, the north-south fluvial corridors of the southern African interior (Okavango, Kwando and Zambezi), bringing flood pulses from the tropics, are likely to have 
been critical for access to food and water resources. They may also have been important as human migratory corridors during times when wider environmental conditions were dry.

In western Zambia at the northeastern margin of the Kalahari basin, an abundance of Stone Age sites have been reported in the Upper Zambezi Valley (UZV) (Inskeep, 1959; Phillipson, 1975a; Phillipson, 1975b; Phillipson,1977). However, little archaeological investigation has taken place since the surveys and excavations of Laurel Phillipson (Phillipson, 1975a\&b, 1977) who worked at open sites along the Zambezi between the Angolan border and Victoria Falls (Phillipson, 1975a). Middle (MSA) and Later (LSA) Stone Age assemblages were excavated, but remain largely under-cited, perhaps because of the difficulty of proving site chronologies. Radiocarbon was the only absolute dating technique available at the time and not all the sites contained charcoal, with none containing bone. Subsequent dating developments have shown the MSA to be well beyond the range of radiocarbon (Barham and Mitchell, 2008; Wadley, 2015), with the onset of the LSA in southern Africa at its upper limits (Villa et al., 2012). A recent road construction project has destroyed many of the sites that Phillipson investigated, but during palaeoenvironmental fieldwork in 2011 an opportunity arose to revisit three remaining, but imminently threatened, Phillipson sites at Chavuma, Sioma $\mathrm{M}$ and Kandanda (Donke gravel pit) to undertake sampling for Optically Stimulated Luminescence (OSL) dating. Here we report the findings of this investigation with the aim of placing the original archaeological data within the chronological context of regional records of palaeolithic and palaeoenvironmental change. We present the sampling and dating for each site, a re-consideration of the archaeological material and a discussion of both the archaeology and their ages in relation to our knowledge of the wider regional archaeological and environmental record.

\subsection{Western Zambia}

Western Zambia (Figure 1) occupies the eastern margin of the 2.5 million $\mathrm{km}^{2}$ Kalahari sedimentary basin (Thomas and Shaw, 1991), and is covered by sand up to 200 m thick (Thomas 1988; Haddon, 1999, 2005). Mean annual rainfall in interior southern Africa decreases from northeast to southwest, controlled principally by the seasonal migration of the tropical rainbelt, decreasing in the UZV from 1,375 $\mathrm{mma}^{-1}$ at Mwinilunga (near the source of the river on the Central African Plateau) to $700 \mathrm{mma}^{-1}$ at Sesheke (Fanshawe, 1971). The wet season extends from November to May in the north of the valley, though is several weeks shorter in its southern reaches, near Katima and Livingstone. The Zambezi moves water through the broad Barotse floodplain, which floods up to $30 \mathrm{~km}$ in width between December and May, steepening and narrowing below Senanga as it incises into Karoo-age basalts of the sub-Kalahari bedrock, creating a series of rapids. The UZV spans an ecological transition zone from dense miombo woodland through woodland-savanna and 
edaphic grassland to a much more xeric-savanna system in the south (Burrough and Willis, 2015). Like the Okavango and Kwando rivers, the UZV carries water from the wetter sub-tropics into drier sub-humid areas. Permanent fluvial channels within the Zambezi floodplain and dambos (shallow wetlands) away from the river provide critical dry season water for modern occupants of the UZV (Burrough et al., 2015). That this was also the case in the past may be reflected in the distribution of archaeological sites along channel margins.

The deep Kalahari sands of western Zambia are also a challenge for locating archaeological deposits, with the majority of sites described by Phillipson (1975a) exposed in road quarries dug in the 1960s and 70s. The sand cover also limited the exposure of rock outcrops for Stone Age people, potentially making resources for lithic tool manufacture scarce. It is notable that many of the UZV in-situ sites are adjacent to major rapids where bedrock is revealed, with a significant proportion of documented lithics manufactured from poor-quality sandstone and quartzites exposed in these locations, including derived quartzite pebbles (Money, 1972). Fluvial erosion may also affect archaeological visibility in this otherwise sandy landscape, which could contribute bias to site distributions.

\subsection{Site locations}

The three investigated sites, Chavuma, Sioma M and Kandanda are shown in Figure 2. Locations and conditions of preservation are outlined briefly here with the archaeological content summarised following the presentation of the dating methods and results.

Chavuma $\left(-13.0946^{\circ} \mathrm{S}, 22.68899^{\circ} \mathrm{E}\right)$

Chavuma Falls archaeological site is on the east bank of the Zambezi at a point where the river is ponded behind a rock barrier as it passes through the Chavuma Hills. It is adjacent to a deep pool at the base of Chavuma Falls and located within a $5 \mathrm{~m}$ section of a thick sandy bank. The base of the section grades into fluvially-deposited pebbles and gravels that rest on the underlying bedrock. The absence of material suitable for ${ }^{14} \mathrm{C}$ dating meant Phillipson (1975a \& b) was unable to provide a chronology.

\section{Sioma M $\left(-16.61269^{\circ} \mathrm{S}, 23.507585^{\circ} \mathrm{E}\right)$}

Exposed in a quarry pit during road construction in 1965, Sioma $M$ is $1.3 \mathrm{~km}$ southwest of the present Zambezi channel and comprises $0.3 \mathrm{~m}$ of hard ferricrete on and in which archaeological material is located. This is overlain by $1.2-2.5 \mathrm{~m}$ of red- yellow sand (Munsell colour 10YR 6/8). 
Kandanda is adjacent to rapids where the Zambezi has cut through bedrock obstructions, forming

114 three valley-side terraces. Phillipson $(1975 a, 1977)$ described the archaeological site as exposed by a

115 large quarry, on the northeast side of the Senanga road between Kandanda village and the

116 Kachekabwe tributary stream. Forty years later, when sampling occurred for this study, the site was

117 again being used as a quarry for road construction, where enlargement had destroyed the majority

118 of Phillipson's 1969 excavation trenches. A few sections remained, including Donke, on the

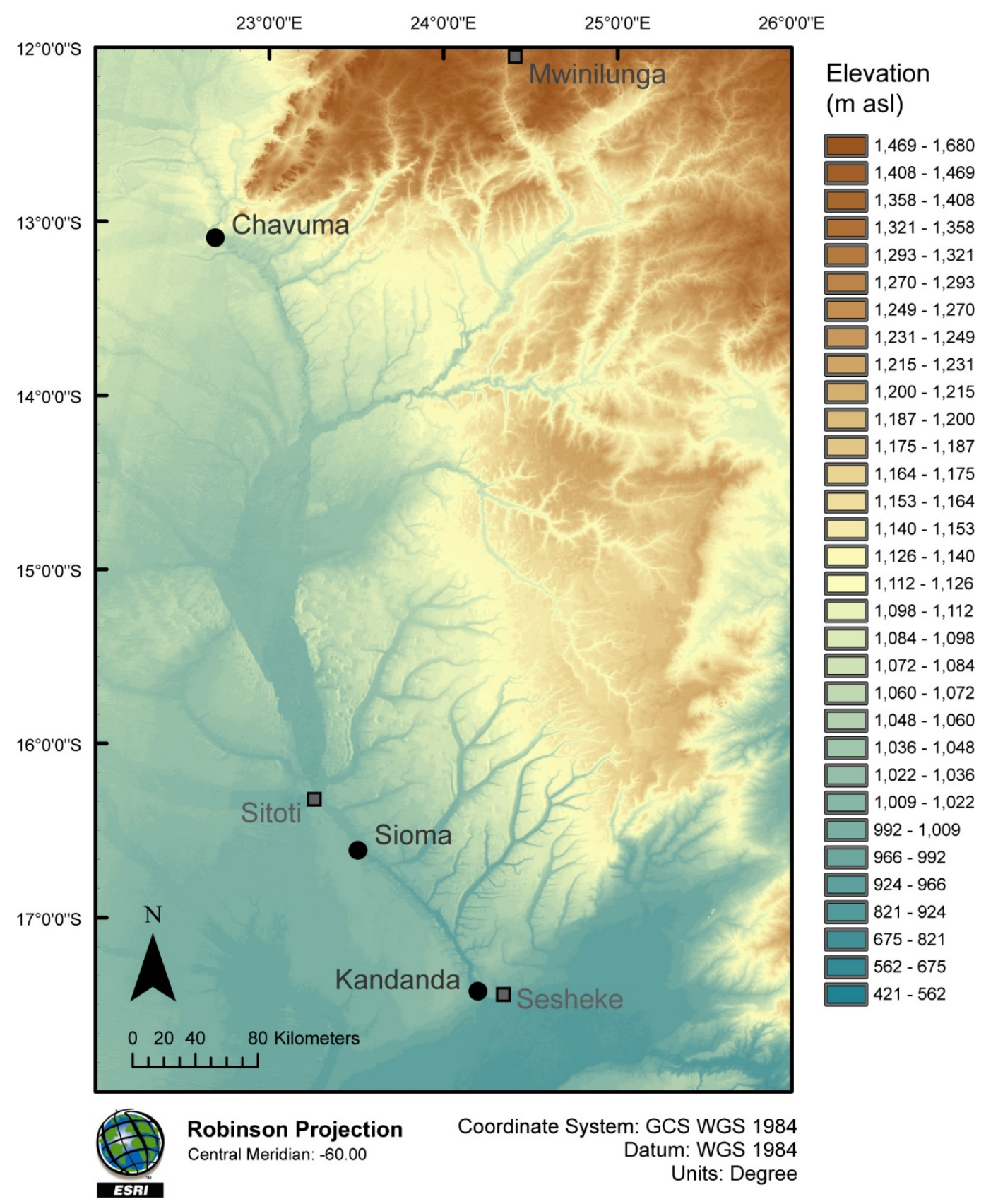


Figure 2: Regional Digital elevation model of the Upper Zambezi Valley (UZV) showing archaeological site locations (filled black circles) investigated in this study. Major settlements discussed in text are also given as grey squares.

\section{OSL Dating}

Sediments for dating were collected at Chavuma (7 samples; ZAM/11/5) and Sioma M (4 samples; ZAM/11/9) using an auger with a light-tight sampling head. At Donke (Kandanda), Phillipson's 1968 test pit remained open; this was dug out and sampled from a cleaned face ( 3 samples; ZAM/11/14). Samples for OSL dating were prepared under subdued red light $(600 \mathrm{~nm})$ conditions at the Oxford Luminescence Dating Laboratory (OLDLab). The outer material (approximately $60 \%$ of an $8 \times 15 \mathrm{~cm}$ tube) from each sample was separated and later used for dosimetry and sedimentological measurements. The centre of the sample (uncontaminated by light) was processed using standard quartz isolation methods e.g. Burrough et al., (2009). A total of 14 samples were dated for this study.

\subsection{Equivalent dose $\left(D_{e}\right)$ Determination}

All samples were dated using 800-1000 individual quartz grain $D_{e}$ measurements per sample. The distribution of $D_{e}$ measurements from single-grain analysis is advantageous for age determinations from Kalahari sediments. First, multiple grain analysis averages $D_{e}$ signals in a manner that can mask erroneous data from 'rogue' grains (c.f. Russell and Armitage, 2012) that would otherwise be rejected in a single grain analysis. These averaging errors will most likely produce overestimated ages. Second, single grain analysis provides a $D_{e}$ distribution that allows a much clearer assessment of depositional and/or post depositional processes, which is critical for informing the choice of age model used to produce the final age. For details on measurement conditions and rejection criteria see supplementary info S1.

\subsection{Dose rate $\left(D^{\prime}\right)$ determination}

Inductively Coupled Plasma Mass Spectrometry (ICP-MS) was used to measure the isotope concentrations $\left({ }^{232} \mathrm{Th},{ }^{238} \mathrm{U}\right.$ and $\left.{ }^{40} \mathrm{~K}\right)$ that determine sample dose rates. For two samples (ZAM/11/5/4 and ZAM/11/5/5), up to 10 small ( $\sim \mathrm{g}$ ) subsamples of bulk sediment were separated for additional ICP measurements to attempt to capture any variability within the sediment. In addition, one sample (ZAM/11/5/4) was density-separated to obtain both heavy mineral and feldspar fractions. The latter was too small by mass to undertake analyses but $U$, Th and $\mathrm{K}$ concentrations in quartz and heavy mineral fractions were measured independently to assess within-sample micro-dosimetry variability. Field gamma spectrometry measurements were also taken for samples ZAM/11/9/2; 9/3; 
9/4 and ZAM/11/14/3 to check that direct radiation measurements returned within-error estimates of the sedimentary gamma dose. Conversion to external beta and gamma components (to account for grain-size, HF etching and moisture content) used the dose-rate conversion and beta attenuation factors of Guerin et al., (2011) and Mejdahl (1979), assuming radioactive equilibrium in the ${ }^{238} \mathrm{U}$ and ${ }^{232}$ Th series. Sample moisture contents during burial were estimated at $10-18 \%$ (Table 1 ) based on 'as found' values. An absolute internal alpha dose uncertainty of $0.012 \mathrm{~Gy} / \mathrm{ky}$ (Vandenberghe et al., 2008) was added in quadrature to the total dose rate error. Cumulative cosmic dose during the burial period was iteratively modelled based on the overlying depositional history (Burrough et al., 2007). Total dose rate uncertainties were calculated using Monte Carlo methods.

\section{Results and Discussion}

\subsection{Equivalent Dose distribution}

Dose rate data, $D_{e}$ estimates and ages are given in Table 1 and 2. $D_{e}$ distributions were consistently broad. Overdispersion (statistical distribution) values, ranging from $43 \%$ to $120 \%$ (Figure S1), lie within the upper end of the range of overdispersion values typical for single grain measurements. In all samples $2-4 \%$ of measured grains had natural signals which far exceeded the growth curve. All accepted De's were below $86 \%$ of saturation $\left(2 * D_{0}\right)$ (Wintle and Murray, 2006). Multiple subsample aliquots for ZAM/11/5/4 and ZAM/11/5/5 suggested bulk dose rate variability of $20 \%$ (subsequently factored into the uncertainty of all sample radioisotope concentrations). Sediments were typically quartz-dominated with a small heavy mineral proportion (0.3-1\% by mass). Heavy minerals create very different dose rates at the inter-grain scale (Figure $3 b$ ), with implications for age model selection. These data suggest a proportion of the observed sample overdispersion can be attributed to dose rate variability at the single grain scale (see supplementary info S2 for details).

Table 1: Radioisotope concentrations and estimated sediment dose rates for each sample.

\begin{tabular}{|c|c|c|c|c|c|c|c|c|c|}
\hline \multirow[b]{2}{*}{$\begin{array}{l}\text { Site } \\
\text { Name }\end{array}$} & \multirow[b]{2}{*}{ Sample ID } & \multicolumn{3}{|c|}{ Radioisotope Concentrations $\mathrm{s}^{\mathrm{a}}$} & \multirow[b]{2}{*}{$\begin{array}{c}\text { Moisture } \\
\text { content (\%) }^{\mathrm{b}}\end{array}$} & \multicolumn{3}{|c|}{ Sediment dose rates (Gy/ka) } & \multirow[b]{2}{*}{$\begin{array}{l}\text { Total dose rate } \\
\text { (Gy/ka) }\end{array}$} \\
\hline & & $\mathrm{K}(\%)$ & Th (ppm) & $U(p p m)$ & & Beta & Gamma & Cosmic $^{d}$ & \\
\hline \multirow{7}{*}{ 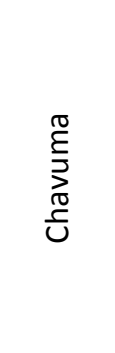 } & ZAM/11/5/1 & 0.05 & 1.64 & 0.38 & 0.10 & 0.11 & 0.12 & 0.21 & $0.43 \pm 0.06$ \\
\hline & ZAM/11/5/2 & 0.05 & 1.47 & 0.36 & 0.10 & 0.10 & 0.11 & 0.20 & $0.41 \pm 0.06$ \\
\hline & ZAM/11/5/3 & 0.07 & 1.86 & 0.45 & 0.10 & 0.13 & 0.14 & 0.20 & $0.47 \pm 0.07$ \\
\hline & ZAM/11/5/4 & 0.03 & 1.44 & 0.39 & 0.10 & 0.09 & 0.11 & 0.19 & $0.39 \pm 0.06$ \\
\hline & ZAM/11/5/5 & 0.04 & 1.41 & 0.43 & 0.15 & 0.09 & 0.10 & 0.18 & $0.37 \pm 0.05$ \\
\hline & ZAM/11/5/6 & 0.05 & 2.10 & 0.47 & 0.18 & 0.11 & 0.13 & 0.16 & $0.40 \pm 0.06$ \\
\hline & ZAM/11/5/7 & 0.05 & 1.40 & 0.40 & 0.18 & 0.09 & 0.10 & 0.16 & $0.35 \pm 0.06$ \\
\hline
\end{tabular}




\begin{tabular}{|c|c|c|c|c|c|c|c|c|c|}
\hline \multirow{4}{*}{ 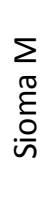 } & ZAM/11/9/1 & 0.07 & 1.40 & 1.75 & 0.10 & 0.26 & 0.25 & 0.22 & $0.73 \pm 0.12$ \\
\hline & ZAM/11/9/2 & 0.07 & 1.16 & 0.68 & 0.10 & 0.14 & $0.11^{\mathrm{c}}$ & 0.21 & $0.49 \pm 0.06$ \\
\hline & ZAM/11/9/3 & 0.08 & 1.54 & 1.00 & 0.10 & 0.19 & $0.15^{c}$ & 0.20 & $0.57 \pm 0.08$ \\
\hline & ZAM/11/9/4 & 0.07 & 1.63 & 1.60 & 0.10 & 0.25 & $0.23^{c}$ & 0.20 & $0.69 \pm 0.10$ \\
\hline & ZAM/11/14/1 & 0.35 & 1.36 & 0.36 & 0.10 & 0.29 & 0.17 & 0.23 & $0.69 \pm 0.06$ \\
\hline & ZAM $/ 11 / 14 / 2$ & 0.36 & 1.60 & 0.37 & 0.10 & 0.31 & 0.18 & 0.23 & $0.72 \pm 0.07$ \\
\hline & ZAM $/ 11 / 14 / 3$ & 0.43 & 1.62 & 0.47 & 0.12 & 0.36 & $0.20^{c}$ & 0.22 & $0.79 \pm 0.08$ \\
\hline
\end{tabular}

$179{ }^{a}$ Error on $\mathrm{K}$, Th and $\mathrm{U}$ estimated at 20\% based on repeat $(\mathrm{n}=10)$ sub-sample ICPMS measurements for samples ZAM/11/5/4 and ZAM/11/5/5

$180 \quad{ }^{\mathrm{b}}$ Average moisture content during burial period estimated from present day water content $\pm 20 \%$

$181 \quad{ }^{\mathrm{C}}$ Measurements made using in situ gamma spectrometry.

$182{ }^{\mathrm{d}}$ Mean cosmic dose rates, (cumulative modelled total cosmic dose (Gy) /age (ka).
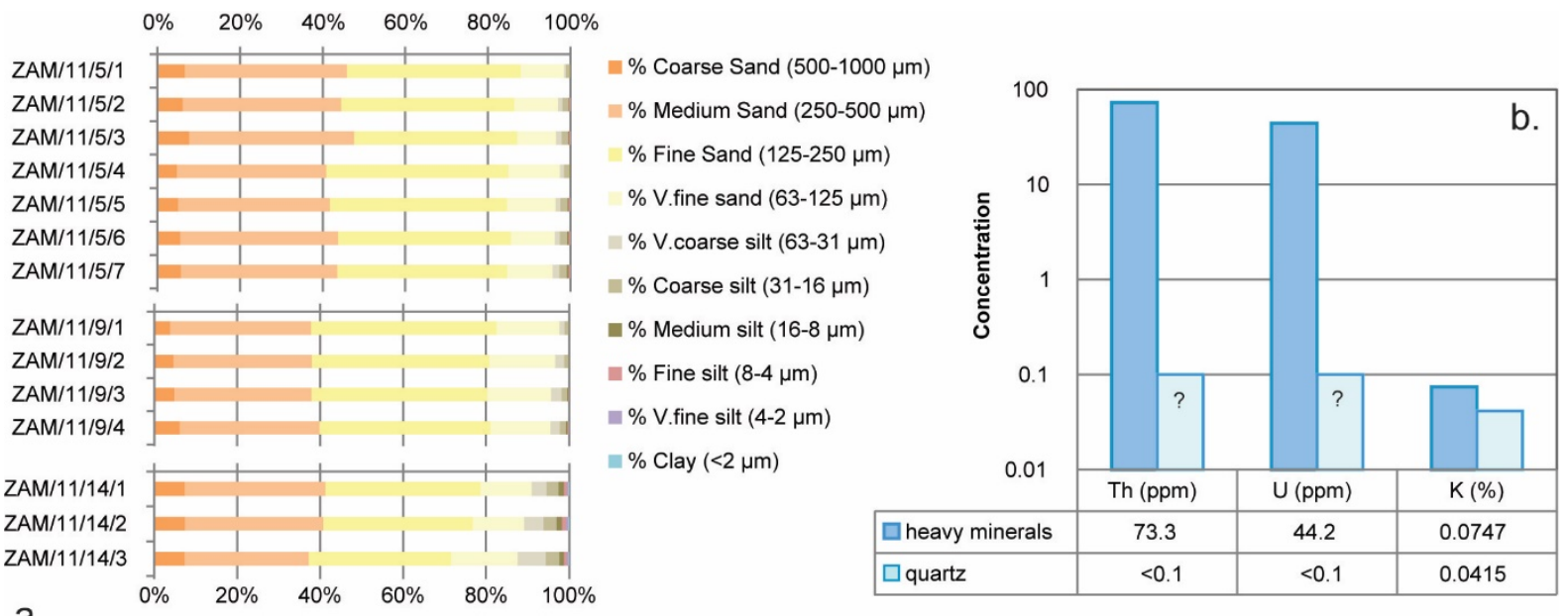

186

187 Figure 3: a) Grain size distribution for each site and b) Separated heavy mineral and quartz fraction 188 radioisotope concentrations from sample ZAM/11/5/5 (question marks indicate measurements below detection limits ( $<0.1 \mathrm{ppm})$.

Table 2: Equivalent dose distribution characteristics and OSL age estimates.

\begin{tabular}{cccccccc} 
Sample ID & $\begin{array}{c}\text { Depth } \\
\mathbf{( m )}\end{array}$ & $\mathbf{n}^{\mathbf{a}}$ & $\begin{array}{c}\text { Equivalent } \\
\text { Dose }^{\mathbf{b}}(\mathbf{G y})\end{array}$ & $\begin{array}{c}\text { Overdis- } \\
\text { persion } \\
\mathbf{( \% )}\end{array}$ & $\begin{array}{c}\text { Central Age } \\
\mathbf{( k a )}\end{array}$ & FMM Age (ka) & $\begin{array}{c}\text { Wgt Mean } \\
\text { Age (ka) }\end{array}$ \\
\hline ZAM/11/5/1 & 1.00 & $115 / 800$ & $1.63 \pm 0.1$ & $114 \%$ & $5.19 \pm 0.76$ & $2.85 \pm 0.33$ & $3.77 \pm 0.41$ \\
ZAM/11/5/2 & 1.50 & $127 / 800$ & $2.72 \pm 0.39$ & $94 \%$ & $9.64 \pm 1.76$ & $6.42 \pm 1.03$ & $6.66 \pm 1.59$ \\
ZAM/11/5/3 & 2.00 & $121 / 800$ & $3.50 \pm 0.35$ & $81 \%$ & $9.60 \pm 1.26$ & $6.81 \pm 1.09$ & $7.55 \pm 1.43$ \\
ZAM/11/5/4 & 2.30 & $105 / 800$ & $3.27 \pm 0.31$ & $66 \%$ & $10.44 \pm 1.91$ & $8.40 \pm 1.31$ & $8.29 \pm 1.67$ \\
ZAM/11/5/5 & 3.00 & $233 / 800$ & $6.99 \pm 0.63$ & $81 \%$ & $25.64 \pm 4.19$ & $16.66 \pm 2.60$ & $18.82 \pm 3.55$ \\
ZAM/11/5/6 & 3.50 & $250 / 900$ & $11.03 \pm 0.60$ & $67 \%$ & $34.48 \pm 5.25$ & $65.51 \pm 9.93$ & $26.69 \pm 4.14$ \\
ZAM/11/5/7 & 4.00 & $155 / 900$ & $14.00 \pm 1.1$ & $64 \%$ & $51.23 \pm 8.11$ & $75.73 \pm 16.61$ & $39.76 \pm 6.86$
\end{tabular}




\begin{tabular}{llllllll} 
ZAM $/ 11 / 9 / 1$ & 0.50 & $105 / 700$ & $1.88 \pm 0.10$ & $73 \%$ & $2.78 \pm 0.41$ & $2.63 \pm 0.34$ & $2.59 \pm 0.35$ \\
ZAM/11/9/2 & 1.20 & $174 / 700$ & $2.41 \pm 0.7$ & $86 \%$ & $5.93 \pm 0.96$ & $4.61 \pm 0.62$ & $4.97 \pm 0.68$ \\
ZAM/11/9/3 & 1.70 & $145 / 700$ & $8.49 \pm 0.21$ & $60 \%$ & $16.78 \pm 2.58$ & $15.02 \pm 2.01$ & $14.95 \pm 2.07$ \\
ZAM/11/9/4 & 2.10 & $188 / 700$ & $9.94 \pm 0.29$ & $80 \%$ & $21.83 \pm 3.73$ & $16.47 \pm 2.44$ & $14.14 \pm 2.17$ \\
& & & & & & & \\
ZAM/11/14/1 & 0.32 & $112 / 800$ & $1.80 \pm 0.05$ & $66 \%$ & $3.18 \pm 0.29$ & $3.09 \pm 0.25$ & $2.63 \pm 0.18$ \\
ZAM/11/14/2 & 0.55 & $102 / 800$ & $3.27 \pm 0.8$ & $43 \%$ & $4.65 \pm 0.48$ & $4.48 \pm 0.49$ & $4.61 \pm 0.41$ \\
ZAM/11/14/3 & 0.80 & $107 / 700$ & $4.74 \pm 0.11$ & $59 \%$ & $6.96 \pm 0.83$ & $6.39 \pm 0.74$ & $6.16 \pm 0.56$ \\
\hline
\end{tabular}

${ }^{a}$ Number of accepted OSL signals / total number of grains measured.

${ }^{\mathrm{b}}$ Weighted mean $D_{e} \pm 1 \sigma$

\subsection{Age model selection}

195

It is unknown whether the highly overdispersed $D_{e}$ s are a common or anomalous feature of the region: despite a long history of Kalahari OSL applications (c.f. Thomas and Burrough, 2013) very few studies have utilised the single grain methodology. It is vital therefore to consider this further.

There are three possible reasons for a large $D_{e}$ distributional spread: i) partial bleaching, whereby grains were insufficiently exposed to sunlight prior to deposition, leaving some with a residual dose from a previous depositional cycle; ii) bioturbation, with grains of different depositional ages moved or mixed by biological processes after deposition; and iii) beta dose rate heterogeneity, whereby grains of the same age were exposed to different dose rates within the sediment. In each case, a different statistical age model can be used to derive an accurate estimate of the specific targeted depositional event associated with the archaeological material. In this case the wide $D_{e}$ distributions likely result from a combination of both beta heterogeneity (see supplementary info S2) and a degree of post-depositional mixing. We assume the latter because of the biologically productive nature of the UZV savanna region (Burrough and Willis, 2015). Zero dose $D_{e}$ values on modern Zambezi fluvial deposits indicate that residual doses from any incomplete bleaching are minimal and unlikely to impact the equivalent dose distributions (Figure S2).

The central age model (CAM: Galbraith et al., 1999) and finite mixture model (FMM: Roberts et al., 2000) were fitted using the Luminescence R package (Kreutzer et al., 2012, 2017). Representative $D_{e}$ estimates were derived assuming overdispersion was caused by dose rate heterogeneity and biological mixing (see S3 for model specification). In addition to CAM and FMM we also calculated weighted mean $D_{e}$ s for each sample. This age model is appropriate where overdispersion can be entirely attributed to between-grain dose rate variability and where radioisotope concentrations, estimated from homogenised bulk sediment sub-samples, will provide average sediment dose rates. 
217 Comparative age/depth relationships for each model are shown in Figures 4 a-c for each archaeological site. Based on the radio-isotope characteristics of the sediment and observations of sediment mixing within this region, we use a Finite Mixture Model (prescribed with overdispersion, $\sigma_{b}$-values, of between 0.3-0.8 as expected from natural/dose-driven grain-to-grain variability) in the final calculation of depositional ages.
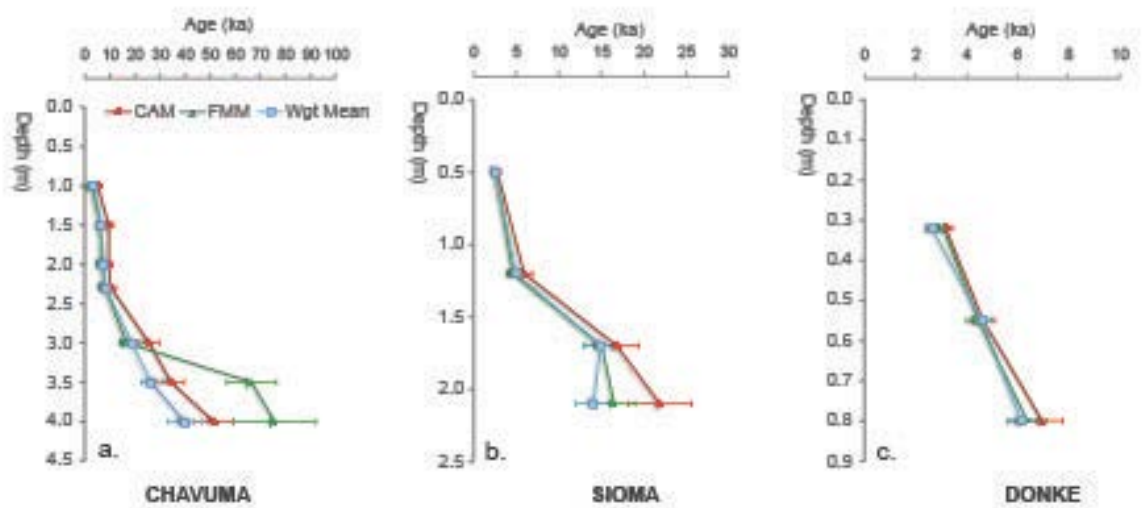

222

Figure 4: Comparative age depth relationships for each site using three age models - The Central Age Model (CAM), the Finite Mixture Model (FMM) and the Weighted Mean (Wgt Mean).

\subsection{Site archaeology and age}

\subsubsection{Chavuma}

227

Phillipson's (1975a,b) excavation at Chavuma Falls was undertaken in a $3.7 \mathrm{~m}$ high sand body (interpreted as an aeolian dune) above the 'land surface' or 'rubble horizon', which slopes down 1.5 $m$ to the modern flood season Zambezi water level. The 1968 excavation occurred in the exposed lower $\sim 1.2 \mathrm{~m}$ of the sand unit, and was carried out in $15 \mathrm{~cm}$ spits down to the 'rubble horizon'. Spits were integrated into separate' levels' based on similarities in selected artefact categories and to a lesser extent in raw material use.

Artefacts were described as comprising sandstones and mudstones with rare quartz and chalcedony, probably sourced from water-polished cobbles on the edge of the Chavuma pool (Figure 5). None of the upper level artefacts were heavily weathered and some pieces showed signs of utilisation. A few artefacts resting on the land surface were heavily abraded but most were moderately fresh in condition. Some older, very abraded pieces were reworked for the production of more recent artefacts (cortex flakes). Phillipson found no consistent statistically-significant differences between assemblages from adjacent spits. One pot sherd was found in Level 1 and one in Level 2; they were regarded as intrusive given their small size and rarity. 


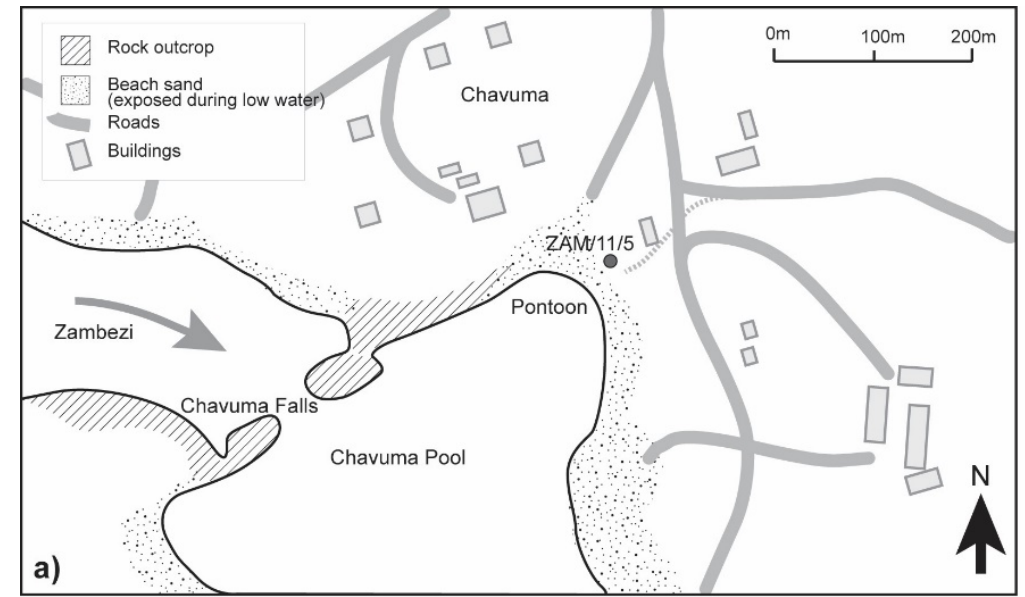

2. OSL dating 2011

1. Phillipson 1968 Excavation $-13.0946^{\circ} \mathrm{S}, 22.68899^{\circ} \mathrm{E}$
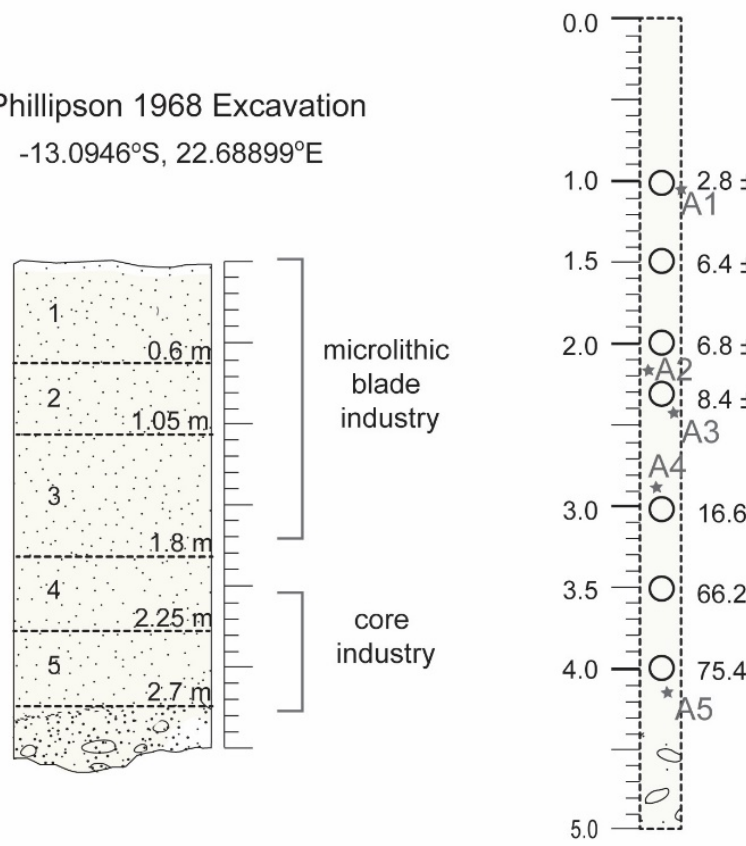

b)

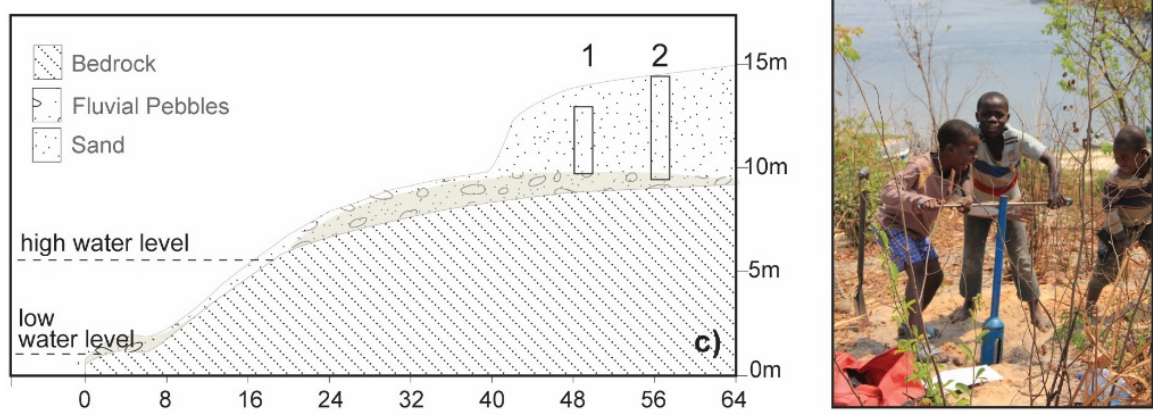

Figure 5: a) Plan view of site location at Chavuma Falls; b) sections within the Chavuma dune from 1) Phillipson's 1968 Excavation showing archaeological levels 1-5 and 2) augered section in 2011 showing location of OSL samples (open circles, ages (FMM model) and artefacts retrieved during augering (marked as ' $A$ ') [we have tied the sections using the position of the basal gravel unit and both sections are drawn on the same scale] ; c) Location of excavation in relation to dune and present day water levels; d) Photograph of the site with Falls in the distance. 
Artefact assemblages and their downward sequence (Table 3, Figure 6A) are very similar to those described by Phillipson (1975a) at Cholwezi, a large site several kilometres north of Chavuma but not investigated further here. The smaller number of retouched artefacts and cores from Chavuma was insufficient to extract meaningful statistical generalisations. Attributions to Industries or Modes were partly based on the presence of distinctive retouched tools and core production strategies, and in part on comparisons with the more numerous Cholwezi sequence. The 'Mode' attribution is based on Clark's (1969) universal scheme of stone tool technologies. In this context, Mode 3 Levallois technology is equated with the Middle Stone Age, based on evidence of core preparation (Levallois technique) and prepared flakes with facetted butts. Mode 5 microlithic technology is equated with Later Stone Age based on the presence of microlithic cores, bladelets and the range of retouched tools made on microliths.

Table 3: Summary assemblage characteristics for each level excavated at Chavuma and the associated classification. Adapted from Phillipson (1975).

\begin{tabular}{|c|c|c|c|c|}
\hline Level & Spit No. & Assemblage characteristics & Condition & $\begin{array}{l}\text { Phillipson } \\
\text { techno- } \\
\text { typological } \\
\text { classification }\end{array}$ \\
\hline 1 & $\begin{array}{l}1-4 \\
(0-0.6 \mathrm{~m})\end{array}$ & $\begin{array}{l}\text { Fine scrapers, crescents, backed blades; radial } \\
\text { flakes comprise } 18-20 \% \text { of all flakes; greatest } \\
\text { use of chalcedony and quartz. }\end{array}$ & Fresh & Mode 5 \\
\hline 2 & $\begin{array}{l}5-7 \\
(0.6-1.05 \mathrm{~m})\end{array}$ & $\begin{array}{l}\text { Finely worked backed implements and } \\
\text { scrapers; radial flakes comprise } 36-40 \% \text { of all } \\
\text { flakes; quartz artefacts are common but } \\
\text { chalcedony is little used. }\end{array}$ & Fresh & Mode 5 \\
\hline 3 & $\begin{array}{l}8-12 \\
(1.05-1.8 \mathrm{~m})\end{array}$ & $\begin{array}{l}\text { Backed implements are much cruder; radial } \\
\text { flakes comprise } 24-31 \% \text { of all flakes. Quartz } \\
\text { and chalcedony rarely used. }\end{array}$ & $\begin{array}{l}\text { Moderately } \\
\text { fresh }\end{array}$ & Mode 5 \\
\hline 4 & $\begin{array}{l}13-15 \\
(1.8-2.25 \mathrm{~m})\end{array}$ & $\begin{array}{l}\text { Scrapers; very little chalcedony and quartz; } \\
\text { increase in the mean flake length; radial flakes } \\
\text { comprise } 24-48 \% \text { but spits fourteen and } \\
\text { fifteen yielded only } 12 \text { and } 19 \text { whole flakes } \\
\text { respectively }\end{array}$ & $\begin{array}{l}\text { Moderately } \\
\text { fresh/slightly } \\
\text { weathered }\end{array}$ & Mode 3 \\
\hline 5 & $\begin{array}{l}16-17 \\
(2.25-2.7 \mathrm{~m})\end{array}$ & $\begin{array}{l}\text { Core implements including two 'fine' bifacial } \\
\text { knives and a bifacial chopper. No flake tools } \\
\text { other than scrapers from the top half of the } \\
\text { level. None of the artefacts was quartz or } \\
\text { chalcedony. }\end{array}$ & $\begin{array}{l}\text { Slightly } \\
\text { weathered. }\end{array}$ & Mode 3 \\
\hline
\end{tabular}


(a)

Level 1

Level 2
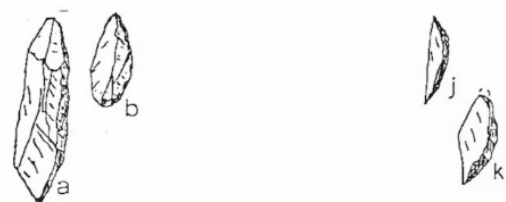

10

50 $100 \mathrm{~mm}$

Level 3

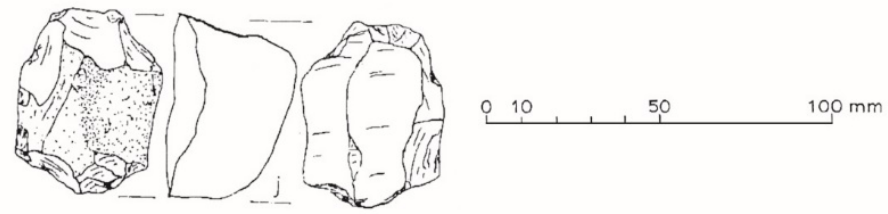

Level 5

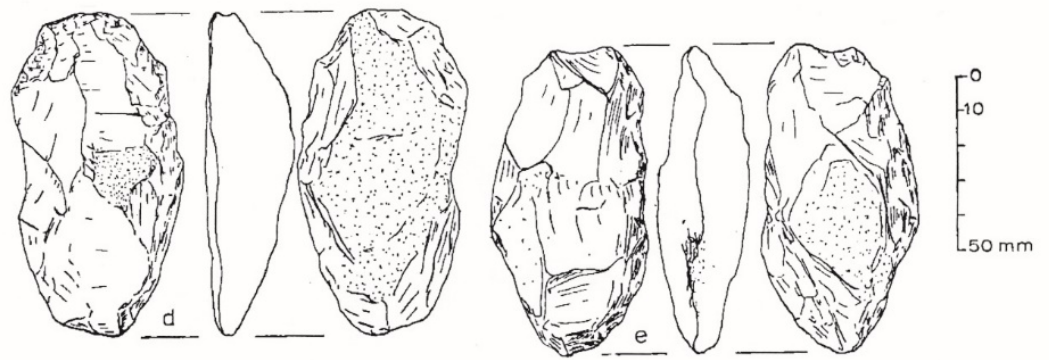

(b) Level 3

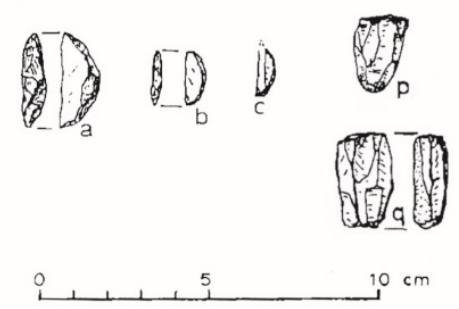

Level 4

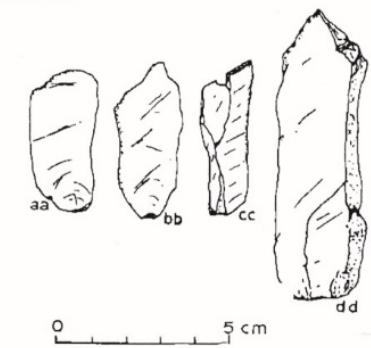

(c)
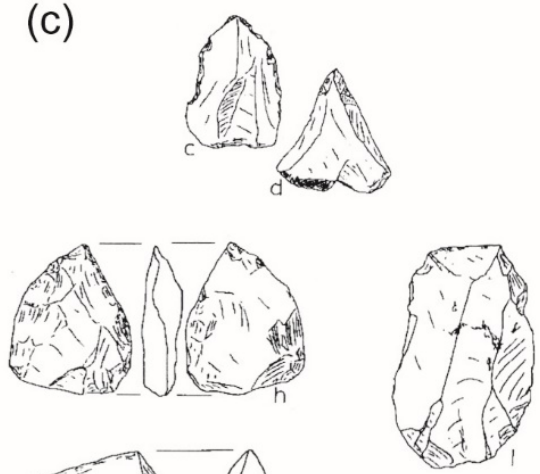

$0+2345 \mathrm{~cm}$

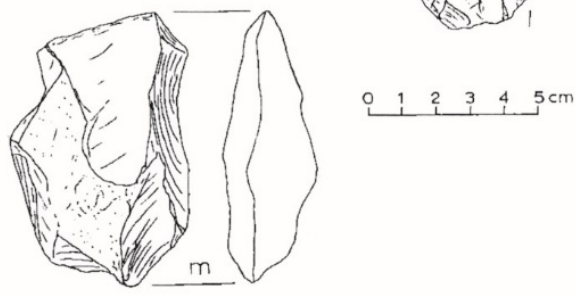

Figure 6: A) Selected Chavuma Falls artefacts as illustrated by L Phillipson and used with permission of the British Institute in Eastern Africa and Azania. Artefact lettering is as appears in Azania Volume $X$, Figures. 16-18. Level 1: backed blades, sandstone (a,b); Level 2: crescents ( $\mathrm{j}=$ mudstone, $\mathrm{k}=$ sandstone) Level 3: high backed ovate radial core ( $\mathrm{j}=$ =mudstone); Level 5: parallel-side bifaces (d,e=mudstone). B) Selected Kadanda artefacts as illustrated by L Phillipson and used with 
permission of the British Institute in Eastern Africa and Azania. Artefact lettering is as appears in Azania Volume XI, Figures. 5-6. Level 3: crescents ( $a, b=$ sandstone; $c=$ chalcedony); single-platform core ( $p$, chalcedony); opposed platform core ( $q$, chalcedony); Level 4: utilized blades (aa-dd, chalcedony). C) Selected Sioma ' $M$ ' artefacts, all chalcedony, as illustrated by L Phillipson and used with permission of the British Institute in Eastern Africa and Azania. Artefact lettering is as appears in Azania Volume XII, Figure 2; unifacial flake points (c,d); bifacial flake point (h); flake cleavers (l, m)

The basal Cholwezi sequence is attributed to Mode 3/MSA based on the presence of prepared cores. There are no prepared cores in the Chavuma sequence, and Phillipson interpreted this record as representing a continuum of the transition from Mode 3 to Mode 5/LSA with its characteristic microlithic forms. Levels 1-3 are clearly Mode 5, but the typological status of Levels 4 and 5 is less certain. They lack microliths and the artefacts are larger; there is a difference in raw material use and Level 4 has unifacial points and some platform preparation on radial cores. We tentatively attribute Level 4 to the MSA/Mode 3. Level 5 lacks points, artefacts are more abraded, and among the small number of retouched tools are large core tools including two parallel-sided 'knives' made on silicified mudstone. The assemblage is too small to assign it to a particular Mode or industry.

Like Phillipson (1975a), we find no statistically significant difference in the grainsize distribution or nature of sediments that would indicate a discontinuity between the lower and upper levels. The OSL data however, indicate a chronostratigraphic break between the lowest parts of the section and the upper sediments. Chronstratigraphic breaks are widely reported form other dating studies of otherwise stratigraphically-featureless Kalahari sands (e.g. Thomas and Burrough 2013). Using the best fit component of the finite mixture model, our results suggest the upper two levels are dated to between $2.9 \pm 0.3 \mathrm{ka}$ and $8.4 \pm 1.3 \mathrm{ka}$ (Figure $5 \mathrm{~b}$ ). The base of Level 3 is dated to $16.7 \pm 2.6 \mathrm{ka}$. Below this, sediments relating to Phillipson's Levels 4 and 5 were dated to $66.5 \pm 9.9$ ka and $75.7 \pm$ 16.6 ka respectively. These overlie a distinct, fluvial terrace demarcated by water-worn pebbles (Figure 5b-c). Importantly, however, the Chavuma dates demonstrate that the archaeological record is not preserved as a continuum as previously thought, and that the transition from a Mode 3 to a Mode 5 technology occurs between $66.5 \pm 9.9$ and $16.7 \pm 2.6 \mathrm{ka}$.

\subsubsection{Sioma $M$}

The record at this site is characterised by large core and flake tools as well as smaller retouched flakes and scrapers (Figure 6B). Phillipson (1975a, b) considered these as two components of a single Mode 3 industry that lacked a chronology. 
The gravel pit was relocated using published descriptions and with help from village elders at Sioma who remembered the 1960 s excavation and its location. Phillipson found material at the interface between an overlying sand deposit and the underlying ferricrete: lithics can be found on the ferricrete surface today. Some pieces were embedded in this duricrust and those not in situ could be linked to the deposit by the adherence of ferricrete and calcrete to their surfaces. All artefacts, both fresh and slightly abraded, were made from 'chalcedony' (fine-grained silcrete) or highly silicified sandstone. Phillipson's assemblage comprised large irregular core and flake tools and smaller retouched flake tools including unifacial and bifacial points, plus scrapers. There is evidence for the deliberate production of radial and triangular flakes, the majority with multifaceted platforms from core preparation. Phillipson $(1975 a, b)$ attributed the assemblage to an early Mode 3 phase, based in part on the production of flake cleavers from prepared cores and the presence of large core tools.

311 In 2011 the pit was degraded, with slumped and eroded margins, but the site context was readily 312 identifiable. The overlying sand described by Phillipson was sampled several meters away from the 313 edge of the pit down to the underlying ferricrete in order to provide a minimum assemblage age 314 (Figure 7). 


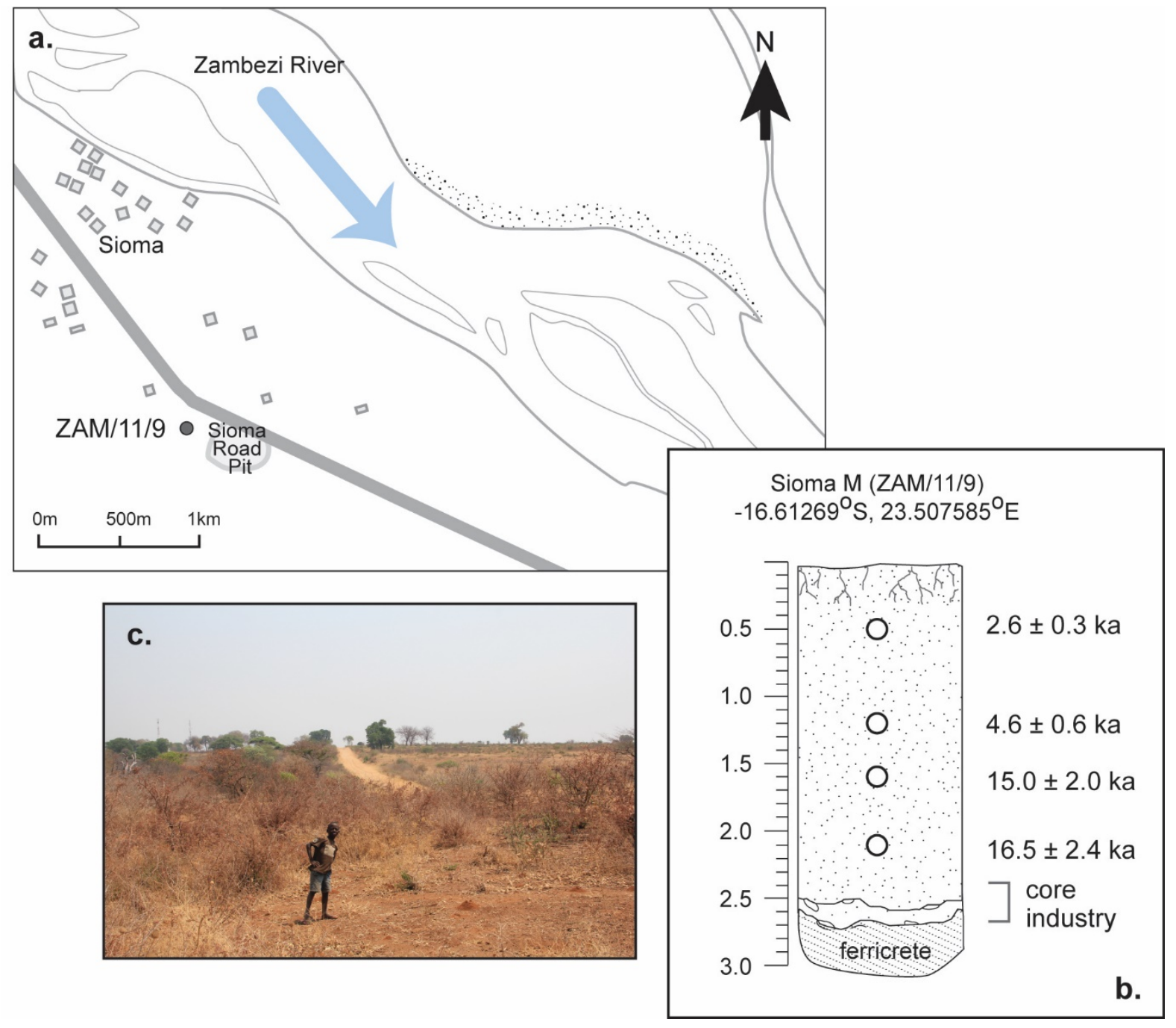

Figure 7: a) Location of Sioma M site with b) OSL dated (open circles) section within Kalahari sand overlying artefact horizon and ferricrete and c) photograph of site location.

The uppermost sand, dated to $2.6 \pm 0.3 \mathrm{ka}$ and $4.6 \pm 0.6 \mathrm{ka}$, is paler, finer and more organic-rich than underlying redder sediments. These contain nodules of calcrete and ferricrete in lower levels and are dated to $15.1 \pm 2 \mathrm{ka}$ and $16.5 \pm 2.5 \mathrm{ka}$ (FMM, Table 2) placing a minimum age on the underlying archaeological assemblage located at the interface between the overlying sand and the underlying ferricrete.

\subsubsection{Donke}

Donke was excavated by Phillipson on the upper-most river terrace which formed the main centre of occupation (Figure 8). The archaeological sequence was "similar to, but more compressed than that of Kandanda" (Phillipson, 1970: page 5). As there is no other information on the Donke trenches we provide a summary of the material from excavations in the neighbouring Kandanda pit (Table 4,

328 Figure 6C). Tools were described as manufactured from homogenous green grey sandstone, 
silicified sandstone with chalcedonic inclusions, sourced from fluvial pebbles and outcropping 'pipe sandstone'. Excavations took place following natural stratigraphic divisions of the deposit but with spit thicknesses never greater than $305 \mathrm{~mm}$. The uppermost fine, grey carbon-rich sands were archaeologically sterile, grading to redder coarser sand below $20 \mathrm{~cm}$. A distinct charcoal concentration was visible at $45 \mathrm{~cm}$ depth at Kandanda, but was not present at Donke. The Donke trench was $1 \mathrm{~m}$ deep, compared to $\sim 2 \mathrm{~m}$ at Kandanda, with a basal unit composed of irregular, friable sandstone overlain by sandstone rocks and artefacts. At Kandanda, the presence of refitted artefacts in level 2 and 3 suggested the deposit was relatively undisturbed.

Table 4: Assemblage characteristics and radiocarbon dates from levels 1-4 of the Kandanda excavation (adapted from Phillipson, 1975).

\begin{tabular}{|c|c|c|c|c|c|c|c|}
\hline Level & $\begin{array}{l}\text { Assemblage } \\
\text { characteristics }\end{array}$ & Condition & Mode & $\begin{array}{l}\text { Radiocar } \\
\text { bon ID }\end{array}$ & Material & $\begin{array}{l}\text { Age } \\
\left({ }^{14} \mathrm{C} \text { yrs BP }\right)\end{array}$ & $\begin{array}{l}\text { Cal Age } \\
\text { (cal yrs BP) }\end{array}$ \\
\hline 1 & $\begin{array}{l}\text { Fragmented potsherds } \\
\text { with organic temper. } \\
\text { Few tools, includes } \\
\text { backed blades and river } \\
\text { pebbles used as } \\
\text { hammer-stones. Pit } \\
\text { with Mongongo nuts. }\end{array}$ & Fresh & Mode 5 & $\begin{array}{l}\text { SR-200 } \\
\text { GX-1579 }\end{array}$ & $\begin{array}{l}\text { Charcoal from pit } \\
\text { infill } \\
\text { Charred post }\end{array}$ & $\begin{array}{l}465 \pm 85 \\
490 \pm 90\end{array}$ & $\begin{array}{l}443 \pm 83 \\
466 \pm 84\end{array}$ \\
\hline 2 & $\begin{array}{l}\text { Utilized small flake } \\
\text { tools, cores, flakes } \\
\text { (including refits to } \\
\text { core) }\end{array}$ & Fresh & Mode 5 & $\begin{array}{l}\text { SR-199 } \\
\text { SR-198 }\end{array}$ & $\begin{array}{l}\text { Scattered charcoal } \\
\text { fragments } \\
\text { Charcoal from } \\
\text { charcoal-rich horizon }\end{array}$ & $\begin{array}{l}1835 \pm 50 \\
2130 \pm 55\end{array}$ & $\begin{array}{l}1701 \pm 73 \\
2053 \pm 85\end{array}$ \\
\hline 3 & $\begin{array}{l}\text { Similar to level } 2 \text { but } \\
\text { with unifacial points. } \\
\text { Also contains broken } \\
\text { bifaces and a bifacial } \\
\text { pick. }\end{array}$ & $\begin{array}{l}\text { Moderately } \\
\text { fresh }\end{array}$ & Mode 5 & SR-201 & $\begin{array}{l}\text { Very small charcoal } \\
\text { fragments from } \\
\text { adjacent squares }\end{array}$ & $3450 \pm 80$ & $3649 \pm 108$ \\
\hline 4 & $\begin{array}{l}\text { Much greater range of } \\
\text { tool types. Flake and } \\
\text { core scrapers, backed } \\
\text { microlithic blades, } \\
\text { choppers and bifacial } \\
\text { core tools. Increased } \\
\text { proportion of radial to } \\
\text { other core types. }\end{array}$ & $\begin{array}{l}\text { Moderately } \\
\text { fresh/slightly } \\
\text { weathered }\end{array}$ & Mode 5 & $\begin{array}{l}\text { GX-1581 } \\
\text { SR-202 } \\
\text { GX-1580 } \\
\text { SR-203 }\end{array}$ & $\begin{array}{l}\text { Charcoal from lowest } \\
\text { humic horizon } \\
\text { Scattered charcoal } \\
\text { fragments } \\
\text { Charcoal from lowest } \\
\text { humic horizon } \\
\text { Scattered charcoal } \\
\text { fragments }\end{array}$ & $\begin{array}{l}3320 \pm 110 \\
3360 \pm 95 \\
3485 \pm 115 \\
3690 \pm 85\end{array}$ & $\begin{array}{l}3508 \pm 132 \\
3550 \pm 114 \\
3699 \pm 147 \\
3960 \pm 126\end{array}$ \\
\hline
\end{tabular}




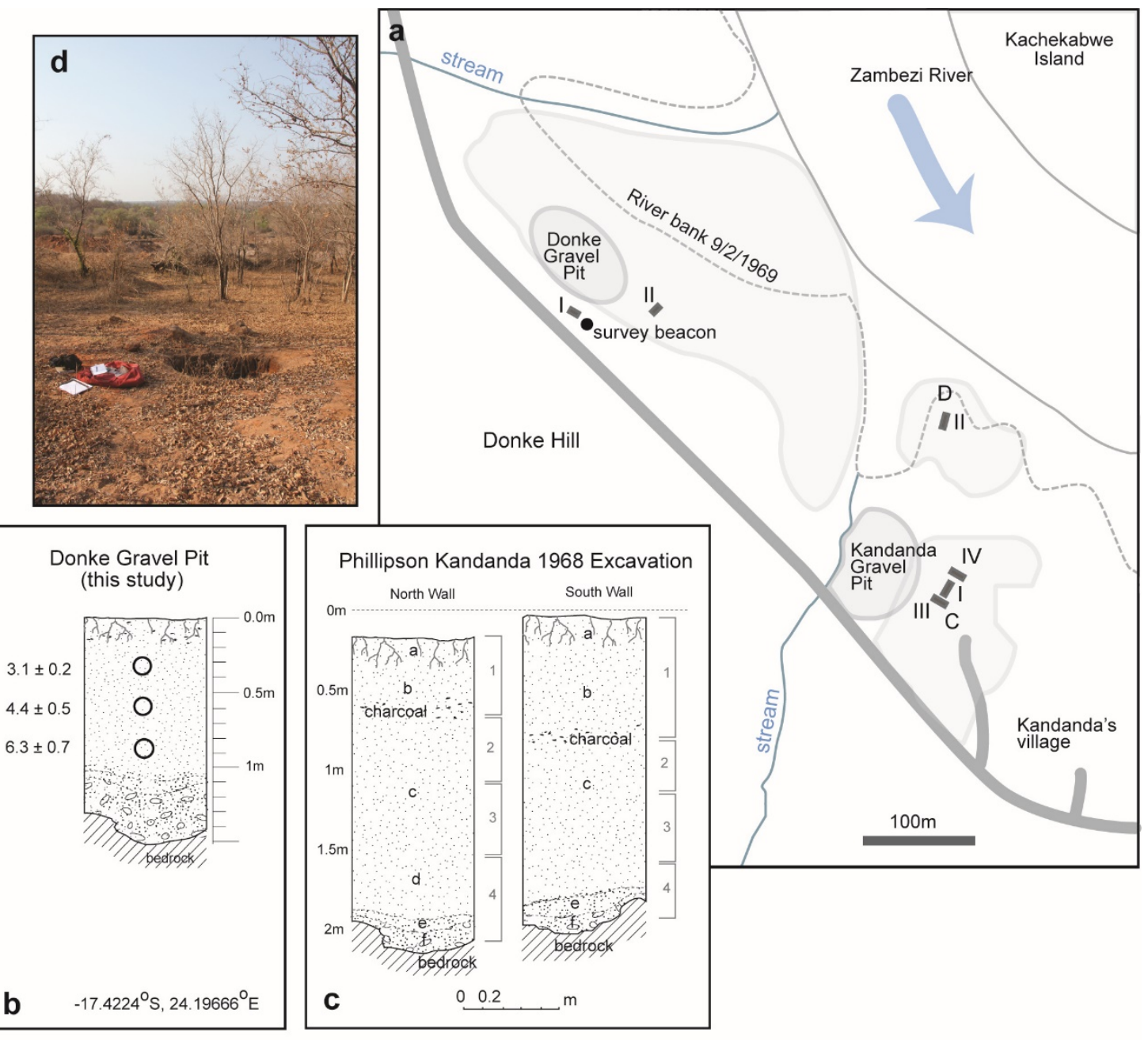

Figure 8: a) Location of Donke Gravel Pit Trench I in relation to the 1968 excavation at Kandanda (now destroyed by a road quarry); b) Pit section and dated OSL sample locations from Donke gravel pit; c) Radiocarbon dated section from Kandanda Trench I with archaeological levels labelled 1-4 (from Phillipson, 1976); c) Photograph of site location looking SE in 2011 with Kandanda road quarry pit in background.

348 Based on the continuity of artefact morphology and technology, particularly in core types, Phillipson argued that the Kandanda archaeological sequence represented a single, continually developing, stone working tradition. The excavated spits were grouped into four levels on the basis of artefact content and stratigraphy. A unity to all four levels was described in that they contain Mode 5 microlithic artefacts, in particular small backed blades. Bladelets and small flakes were found in all levels along with radial cores and flakes. Level 4 differed in having a greater number and variety of core tools and a higher proportion of radial cores. Artefacts were larger in Levels 3 and 4 with a trend towards greater use of sandstone in the lower levels. The co-occurrence of microliths with large cores was a distinctive feature of Level 4 . The presence of blades, technically a feature of Mode 4 assemblages, highlights the diverse technologies produced. A noteworthy feature of Level 1 
was the presence of organic tempered pottery which has wider regional significance, discussed below.

360

361

362

363

364

365

366

367

368

369

370

371

372

373

374

375

376

377

378

379

380

381

382

383

384

385

386

387

388

389

Radiocarbon ages from charcoal at Kandanda placed the sequence well within the Mid- and Late Holocene (Table 4). There are, however, issues with the reliability of the sequence arising from the sampling strategy and bioturbation. The single date from Level 3 (lab no. SR-201) is considered as out of place as it disrupts an otherwise coherent sequence. Phillipson notes that the sample consisted of small charcoal fragments combined from four adjacent squares, and that ants and roots had disturbed the sediments in this level (Phillipson 1978:79-80). Composite samples are also reported from Level 2 (SR-199) and Level 4 (SR-202; SR-203).

OSL measurements from the Donke trench place the upper levels of this section at $3.1 \pm 0.3 \mathrm{ka}$ and $4.5 \pm 0.5 \mathrm{ka}$. The lower part of the $1 \mathrm{~m}$ section dates to $6.4 \pm 0.7 \mathrm{ka}$. The more compressed nature of the section makes it hard to precisely relate these dates to the Kandanda archaeological sequence, but they do support the Holocene age proposed by Philipson (1975a).

\section{Implications of the OSL chronology for Upper Zambezi sites}

The new OSL ages we present suggest that, at least for Chavuma, the ages of the lowest archaeological units were significantly underestimated by Phillipson with the transition from Mode 3 to Mode 5 technology occurring before $16.6 \mathrm{ka}$. At Sioma $\mathrm{M}$, we place a minimum age of $16.5 \pm 2.5$ ka on the Mode 3 archaeology. Taking these two sites together, we infer a discontinuous sedimentary record between the MSA (Mode 3) and LSA (Mode 5). The inability to firmly relate the (now destroyed) archaeological sequence from Kandanda to the new OSL ages from the remaining Donke Trench is problematic, though the sedimentary deposits do appear to affirm a Mid-Late Holocene age for the upper terrace sediments.

The nearest comparable Late Pleistocene archaeological record comes from Mumbwa Caves, $380 \mathrm{~km}$ east of the Zambezi (Figure 1) where there are clear gaps in the sequence that may be correlated with climate change. This site was occupied 130-105 ka, abandoned between 105- $40 \mathrm{ka}$, reoccupied briefly then abandoned again between $40 \mathrm{ka}-15 / 12 \mathrm{ka}$, after which the technology is Mode 5 (Barham, 2000). There is also evidence of a Mid-Holocene occupation hiatus between 6 and $2 \mathrm{ka}$. Barham (2000) speculated that shifts in the availability of surface water were linked to regional changes in hydrology, and ultimately climate change governed the human use of the site. At Chavuma, the MSA/Mode 3 assemblage is dated to $66 \pm 9.9 / 75 \pm 16.7$ ka (i.e. within errors) spanning both wetter and drier periods within the Kalahari basin; relevant given the importance of the Zambezi as a water source in the region. The LSA assemblages dated here also span a broad range of 
climatic/environmental conditions, although the resolution of regional palaeoclimate records is currently too spatially and temporally coarse to allow relationships between human presence and environmental change to be tested. The proposition that fluvial corridors act as refugia in dry times also remains to be tested. The recurrent occupation of Chavuma, despite its open air context, probably reflects its position close to a persistent barrier-induced pool on the Zambezi, subject to less channel migration and drying than meander belt zones further south on the floodplain.

All archaeological sites in Zambia that post-date the Last Glacial Maximum (LGM) are Mode 5 in character with local variations in the proportions of microlithic tools relative to larger forms. There is a relative uniformity in the Late Glacial Mode 5 of Zambia (Nachikufan I) with local differences emerging in the early Holocene (Barham and Mitchell, 2008). Separate Mode 5 industries have been recognised in eastern, northern and central Zambia (Makwe, Phillipson, 1976; Nachikufan II,III, Miller, 1970; Group 1, Musonda, 1984; Zambian Wilton, Clark, 1950; ) but they can be subsumed within a spatially and chronologically variable Nachikufan Industrial Complex (Barham and Mitchell, 2008). With the exception of Phillipson's work, there are no dated sites in western Zambia. The LSA complex at Gwisho, on the central Zambian Kafue Flats ( $\sim 00 \mathrm{~km}$ east of the UZV) is dated between $3600 \pm 70$ BP to $4700 \pm 100$ BP (3935 cal BP [mean, 106 sigma] - 5361 cal BP [mean, 152 sigma]) (Gabel, 1965; Fagan and Van Noten, 1971) making it comparable in age to the Kandanda Level 4 deposit and overlapping chronologically with the Donke pit OSL ages. The occupants of Gwisho made microlithic tools (backed flakes) and large scraping, cutting, chopping and pounding tools comparable to some of the macrolithic components seen at Kandanda. At Kamusongolwa Rockshelter in northwestern Zambia ( $300 \mathrm{~km}$ east of Chavuma) there are two composite radiocarbon dates that bracket the LSA between 13,300 \pm 250 (BP) $(15,925$ cal BP [mean, 375 sigma]) at the base to 4,000 $\pm 105 \mathrm{BP}$ (4417 cal BP [mean, 171 sigma]) at the top, with a gap of 3000 years between the overlying Iron Age occupation (Savage, 1983). The Mode 5 technology is characterised by backed flakes and blades, comparable to the wider Zambian microlithic tradition including the material from the UZV. The calibrated age of the lower LSA overlaps with that of Sioma $\mathrm{M}$ and Chavuma and provides further evidence of a Late Glacial Mode 5 in northwestern Zambia. The calibrated Mid-Holocene assemblage from Kamusongolwa also overlaps with Kandanda and Donke Pit.

A combination of microlithic and macrolithic technology characterises the LSA on the margins of the Congo basin to the north. For the Chavuma/Cholwezi transitional Mode 3-Mode 5 sequence, Phillipson (1975a) proposed typological links with the Tshitolian Industry which appears to span the Late Glacial to Mid-Holocene (Cornelissen 2013, but see Taylor, 2016). The Tshitolian, however, is 
not well constrained chronologically and comparisons with Zambian Mode 3 or Mode 5 assemblages are currently difficult to sustain.

There has been very little systematic archaeological research within the wider Kalahari basin, with the few reliable MSA ages come from Toteng near Lake Ngami at $52 \pm 7$ ka (Brook et al., 2008); \# Gi pan, western Botswana, at $77 \pm 11$ ka (Brooks et al., 1990); and at Tsodilo between $54 \pm 10$ ka (Ivester et al., 2010) and $94 \pm 9$ ka (Feathers, 1997; see also Staurset and Coulson (2014) and Robbins et al. (2016) for considerations of chronology), all in northern Botswana. The earliest microlithic LSA technology ages are from the Tsodilo Hills ( $\sim 300 \mathrm{~km}$ to the SW of the UZV) with an increase in small retouched tools between c.36-30 ka (Ivester et al., 2010; Feathers, 1997; Robbins et al., 2000) following a 'large blade' transitional MSA/LSA phase from $55 \pm 4.7$ ka to $37 \pm 1.3$ ka (Brooks et al., 1990; Feathers, 1997) (Figure 9a). Thereafter the pattern of technological change in this northern belt of southern Africa differs slightly to that south of the Kalahari. In the study region, bladelet based microlithic Mode 5 industries continue well into the Pleistocene/Holocene transition (Mitchell, 2002 ). To the south of the Kalahari basin, the Later Stone Age presents a more regionally variable technological record from c.20-12 ka of microlithic (Robberg Industry) then an early Holocene c. 12-8 ka macrolithic (Oakhurst Complex) and microlithic (Wilton Industry) between c.8 -4 ka with macrolithic technologies post-4 ka (Vogelsang et al., 2010, Sealy, 2016).

As a generalisation, the LSA in the region of the UZV is still too poorly described and dated to make firm attributions to better known industries to the south and north. Systematic research is needed along the Upper Zambezi Valley to resolve lingering typological and chronological issues.

\subsection{Palaeoenvironmental change and the regional Mode 3-Mode 5 Transition}

Previous archaeological studies, particularly from inland cave sites have revealed marked changes in the content and periodicity of occupation during the late Pleistocene, with gaps in the record tentatively related to records of palaeoenvironmental change (Barham, 2001). One theory is that fluvial systems such as the Zambezi may have offered refugia during regionally dry conditions in the Pleistocene (Barham, 2001; Avery, 2003). The emergence, in the last decade, of more robust records of hydrological and palaeo-environmental change (Figure 9a) potentially provides a basis for testing this theory. However, this is somewhat countered by overwhelming evidence that wetting and drying was not spatially homogenous within southern Africa through the late Quaternary (e.g. Figure

452 9b). These new records cannot therefore be spatially extrapolated without care. The idea of 453 homogenous 'dry periods' that extended across the continent (e.g. during the LGM) are increasingly rejected (Thomas et al., 2012) in favour of more nuanced models of tropical climate response 
455 (Singarayer and Burrough, 2015). For example, it seems likely that the LGM in both eastern and central southern Africa were, on the whole, wetter in comparison to regions to the southeast and northeast (Figures 9a and b). This spatial pattern of climate/environmental conditions however, changes over time. In the context of the UZV and the broader Kalahari basin the temporal and spatial resolution of palaeoclimatic and archaeological evidence is low but both Mode 3 and Mode 5 assemblages appear to span regionally wetter and drier conditions, suggesting the upper Zambezi valley was suitable for occupation during a range of environmental conditions.

Figure 9: a) Temporal variability of climate/environment as shown by palaeorecords showing i) dated archaeological records at Chavuma in relation to ii) insolation variation at $15^{\circ} \mathrm{N}$ and $\mathrm{S}$ (Berger and Loutre, 1991) and iii) dated regional MSA, LSA and Transitional archaeological records in the

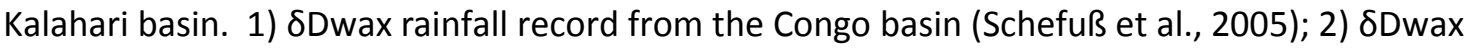
eastern Namib/western Kalahari rainfall record (Collins et al., 2014); 3) Shoreline records from the megalake Makgadikgadi system (Burrough et al., 2007; Burrough and Thomas, 2008; Burrough et al., 2009); 4) Rainfall record inferred from grainsize characteristics in the Tswaign Crater, South Africa (Partridge et al., 1997); 5) Rainfall intensity over the Zambezi Fan סDwax (\%o) (Schefuß et al., 2011; Wang et al., 2013); 6) Shoreline records inferring high stands at Lake Chilwa (Thomas et al., 2009); 7) Lake level record from Malawi (Scholz et al., 2007; Cohen et al., 2007); 8)Tanganyika $\delta$ Dwax (\%) (Tierney et al., 2008). Numbers refer to site locations on Figure 9b. Blue bars highlight potentially wetter conditions in the Kalahari basin. $\mathbf{b})$ : An example of spatial variability in past climate patterns across the southern African interior. In this case we show model data from the HadCM3 model (modified from Singarayer and Burrough (2015)) with annual precipitation anomalies for LGM-PI in $\mathrm{mm} /$ day. Overlayed are LGM conditions from regional palaeorecords shown in figure $9 \mathrm{a}$ and the MSA and LSA sites plotted in figure 1.

Wetter/drier conditions would, no doubt, have impacted the landscape, habitat use and perhaps the geographical range of early humans, resulting in resource shortages in some areas and abundance in others. This emerging picture of spatial heterogeneity of palaeoclimate change (Fig $9 \mathrm{~b}$ ) may go some way to explaining regional patterns of human resource use and changes in lithic technology but more detailed records (both archaeological and palaeoenvironmental) are required before these links can be robustly examined.

\section{Conclusion}

Single grain OSL dates from Chavuma on the Upper Zambezi Valley suggest the MSA/Mode 3 archaeological record is much older than initially hypothesised (Phillipson, 1978) and likely dates to $66.5 \pm 9.9-75.7 \pm 16.6 \mathrm{ka}$. The Mode 3 to Mode 5 transition at this site occurred within the period between $66.5 \pm 9.9 \mathrm{ka}$ and $16.7 \pm 2.6 \mathrm{ka}$. Further south at Sioma $\mathrm{M}$, sterile Kalahari sands deposited on ferricrete overlying Mode 3 tools date to $16.5 \pm 2.5 \mathrm{ka}$, placing a minimum age on the underlying archaeological record. Donke pit was the only remaining section at Kandanda not destroyed by road quarrying though there is little existing information with regard to the archaeological units except that it is a 'compressed' version of the Kandanda site.

Barham (2000) suggested that human use of the archaeological sites at Mumbwa Caves was linked to the availability of surface water in the vacinity. In the UZV there is similar chronological discontinuity between occupation phases although, at least at Chavuma, part of the record may be missing due to periods of fluvial erosion. What does seem clear from these re-dated sites is that the 
'Mode 3' (MSA) assemblages described by Phillipson (1975a, b) in the Upper Zambezi Valley significantly pre-date the LGM and are chronologically consistent with the handful of sites dated within the Kalahari in Botswana (Figure 9).

At all of these sites, when the available records of palaeohydrological change are examined, the archaeological assemblages appear to span a broad range of climate/environmental conditions. However, there are still too few high-resolution palaeoenvironmental and archaeological records from the interior of southern Africa to draw robust relationships between long-term regional climate change and observations in the archaeological record. What is increasingly clear however, is that there is strong spatial variability in patterns of climate change across southern Africa. Rather than extrapolation to distant palaeoclimate records, theoretical models linking changes in regional resource distribution and predictability with hunter-gatherer strategies of mobility, settlement patterning, foraging range size and tool design (Ambrose and Lorenz, 1990, McCall, 2007) offer a potentially more useful perspective for understanding the regional diversity in the archaeological record as the resolution of these records improves.

\section{Acknowledgements}

This research was carried out under Leverhulme grant Floods and Droughts in the Upper Zambezi Valley (Award No: F/08 773/I) and the University of Oxford Fell Fund. We gratefully acknowledge the National Heritage Conservation Commission for the granting of a research permit to conduct the research, and the Livingstone Museum for their assistance and valued support in Zambia. We thank two anonymous reviewers for their helpful comments.

\section{Figure and Table Captions}

Figure 1: Published MSA and LSA archaeological site locations within southern Africa. The upper Zambezi region is marked with a red box. 1) Congo basin; 2) eastern Namib/western Kalahari rainfall record; 3) Megalake Makgadikgadi; 4) Tswaing Crater; 5) Zambezi Fan; 6) Lake Chilwa; 7) Lake Malawi; 8) Lake Tanganyika; Mf = Mufo; Cal3 = Calunda III; Chv = Chavuma; Si = Sioma M; Knd = Kandanda; Kal = Kalambo Falls; $\mathrm{Mz}=$ Manzi River; $\mathrm{MC}=$ Mumbwa Caves; GS=Gwisho Springs; $\mathrm{TR}=$ Twin Rivers; LH = Leopards Hill Cave; Kmb = Kalemba Rock Shelter; Tso = Tsodilo; Gi = \#Gi; Tg = Toteng.

Figure 2: Regional Digital elevation model of the Upper Zambezi Valley (UZV) showing archaeological site locations (filled black circles) investigated in this study. Major settlements discussed in text are also given as grey squares.

Figure 3: a) Grain size distribution for each site and b) Separated heavy mineral and quartz fraction radioisotope concentrations from sample ZAM/11/5/5 (question marks indicate measurements below detection limits (<0.1 ppm). 
534 Figure 4: Comparative age depth relationships for each site using three age models - The Central

535 Age Model (CAM), the Finite Mixture Model (FMM) and the Weighted Mean (Wgt Mean).

536 Figure 5: a) Plan view of site location at Chavuma Falls; b) sections within the Chavuma dune from 1)

537 Phillipson's 1968 Excavation showing archaeological levels 1-5 and 2) augered section in 2011

538 showing location of OSL samples (open circles, ages (FMM model) and artefacts retrieved during

539 augering (marked as ' $A$ ') [we have tied the sections using the position of the basal gravel unit and

540 both sections are drawn on the same scale] ; c) Location of excavation in relation to dune and

541 present day water levels; d) Photograph of the site with Falls in the distance.

542 Figure 6: A) Selected Chavuma Falls Dune artefacts as illustrated by L Phillipson and used with 543 permission of the British Institute in Eastern Africa and Azania. Artefact lettering is as appears in

544 Azania Volume X, Figures. 16-18. Level 1: backed blades, sandstone (a,b); Level 2: crescents

545 ( $j=$ =mudstone, $k=$ sandstone) Level 3: high backed ovate radial core ( $j=$ =mudstone); Level 5: parallel-side

546 bifaces ( $d, e=$ mudstone). B) Selected Kadanda artefacts as illustrated by L Phillipson and used with

547 permission of the British Institute in Eastern Africa and Azania. Artefact lettering is as appears in

548 Azania Volume XI, Figures. 5-6. Level 3: crescents (a,b=sandstone; c=chalcedony); single-platform

549 core ( $p$, chalcedony); opposed platform core ( $q$, chalcedony); Level 4: utilized blades (aa-dd,

550 chalcedony). C) Selected Sioma ' $M$ ' artefacts, all chalcedony, as illustrated by L Phillipson and used

551 with permission of the British Institute in Eastern Africa and Azania. Artefact lettering is as appears

552 in Azania Volume XII, Figure 2; unifacial flake points (c,d); bifacial flake point (h); flake cleavers (l, $\mathrm{m}$ )

553 Figure 7: a) Location of Sioma M site with b) OSL dated (open circles) section within Kalahari sand

554 overlying artefact horizon and ferricrete and c) photograph of site location.

555 Figure 8: a) Location of Donke Gravel Pit Trench I in relation to the 1968 excavation at Kandanda 556 (now destroyed by a road quarry); b) Pit section and dated OSL sample locations from Donke gravel 557 pit; c) Radiocarbon dated section from Kandanda Trench I with archaeological levels labelled 1-4 558 (from Phillipson, 1976); c) Photograph of site location in 2011 looking SE with Kandanda road quarry 559 pit in background.

560 Figure 9: a) Temporal variability of climate/environment as shown by palaeorecords showing i) 561 dated archaeological records at Chavuma in relation to ii) insolation variation at $150 \mathrm{~N}$ and $\mathrm{S}$ (Berger 562 and Loutre, 1991) and iii) dated regional MSA, LSA and Transitional archaeological records in the 563 Kalahari basin. 1) $\delta$ Dwax rainfall record from the Congo basin (Schefuß et al., 2005); 2) $\delta$ Dwax 564 eastern Namib/western Kalahari rainfall record (Collins et al., 2014); 3) Shoreline records from the 565 megalake Makgadikgadi system (Burrough et al., 2007; Burrough and Thomas, 2008; Burrough et al., 566 2009); 4) Rainfall record inferred from grainsize characteristics in the Tswaign Crater, South Africa 567 (Partridge et al., 1997); 5) Rainfall intensity over the Zambezi Fan SDwax (\%o) (Schefuß et al., 2011;

568 Wang et al., 2013); 6) Shoreline records inferring high stands at Lake Chilwa (Thomas et al., 2009); 7) 569 Lake level record from Malawi (Scholz et al., 2007; Cohen et al., 2007); 8)Tanganyika SDwax (\%o) 570 (Tierney et al., 2008). Numbers refer to site locations on Figure 9b. Blue bars highlight potentially 571 wetter conditions in the Kalahari basin.

572 b): An example of spatial variability in past climate patterns across the southern African interior. In 573 this case we show model data from the HadCM3 model (modified from Singarayer and Burrough 
574 (2015)) with annual precipitation anomalies for LGM-PI in mm/day. Overlayed are LGM conditions

575 from regional palaeorecords shown in figure 9a and the MSA and LSA sites plotted in figure 1.

576 Table 1: Radioisotope concentrations and estimated sediment dose rates for each sample

577 Table 2: Equivalent dose distribution characteristics and OSL age estimates.

578 Table 3: Summary assemblage characteristics for each level excavated at Chavuma and the 579 associated classification. Adapted from Phillipson (1975).

580 Table 4: Assemblage characteristics and radiocarbon dates from levels 1-4 of the Kandanda 581 excavation (adapted from Phillipson, 1975). *see Figure 8

582

583 References

584 Adamiec G and Aitken MJ (1998) Dose-rate conversion factors: Update. Ancient TL 16: 37-50.

Ambrose SH and Lorenz KG (1990) Social and ecological models for the Middle Stone Age in

586 Southern Africa. In: Mellars P (ed) The Emergence of Modern Humans: An Archaeological

587 Perspective. Edinburgh: Edinburgh University Press, 3-33.

588 Avery DM (2003) Early and middle Pleistocene environments and hominid biogeography;

589 micromammalian evidence from Kabwe, Twin Rivers and Mumbwa Caves in central Zambia.

590 Palaeogeography, Palaeoclimatology, Palaeoecology 189: 55-69.

591 Backwell LR, McCarthy TS, Wadley L, et al. (2014) Multiproxy record of late Quaternary climate

592 change and Middle Stone Age human occupation at Wonderkrater, South Africa. Quaternary Science

593 Reviews 99: 42-59.

594 Barham L (2001) Central Africa and the emergence of regional identity in the Middle Pleistocene. In:

595 Barham L and Robson Brown K (eds) Human Roots: Africa and Asia in the Middle Pleistocene. Bristol:

596 Western Academic and Specialist Press, $65-80$.

597 Barham L and Mitchell P (2008) The First Africans: African Archaeology from the Earliest Toolmakers

598 to Most Recent Foragers, Cambridge: Cambridge University Press.

599 Barham LS (2000) The Middle Stone Age of Zambia, South Central Africa. Bristol: Western Academic 600 and Specialist Press.

601 Berger A and Loutre MF (1991) Insolation values for the climate of the last 10 million years.

602 Quaternary Science Reviews 10: 297-317.

603 Brook GA, Srivastava P, Brook FZ, et al. (2008) OSL chronology for sediments and MSA artefacts at

604 the Toteng quarry, Kalahari Desert, Botswana. South African Archaeological Bulletin 63: 151-158.

605 Brooks AS (1984) San land-use patterns, past and present: implications for southern African

606 prehistory. In: Hall M, Avery G, Avery DM, et al. (eds) Frontiers: Southern African Archaeology Today.

607 BAR International Series 207, 40-52. 
Brooks AS, Hare PE, Kokis JE, et al. (1990) Dating Pleistocene archaeological sites by protein diagenesis in ostrich eggshell. Science 248: 60-64.

Burrough SL (2016) Late Quaternary environmental change and human occupation of the southern African interior. In: Jones S and Stewart BA (eds) Africa from MIS 6-2: Population Dynamics and Paleoenvironments. Dordrecht: Springer, 161-174.

Burrough SL and Thomas DSG (2008) Late Quaternary lake-level fluctuations in the Mababe Depression: Middle Kalahari palaeolakes and the role of Zambezi inflows. Quaternary Research 69: 388-403.

Burrough SL and Thomas DSG (2009) Geomorphological contributions to palaeolimnology on the African continent. Geomorphology 103: 285-298.

Burrough SL and Thomas DSG (2013) Central southern Africa at the time of the African Humid Period: A new analysis of Holocene palaeoenvironmental and palaeoclimate data. Quaternary Science Reviews 80: 29-46.

Burrough SL, Thomas DSG and Bailey RM (2009) Mega-Lake in the Kalahari: A Late Pleistocene record of the Palaeolake Makgadikgadi system. Quaternary Science Reviews 28: 1392-1411.

Burrough SL, Thomas DSG, Orijemie EA, et al. (2015) Landscape sensitivity and ecological change in western Zambia: The long-term perspective from dambo cut-and-fill sediments. Journal of Quaternary Science 30: 44-58.

Burrough, SL, Thomas, DSG, Orijemie, EA, Willis, KJ (2015). Landscape sensitivity and ecological change in western Zambia: The long-term perspective from dambo cut-and-fill sediments, Journal of Quaternary Science 30: 44-58.

Burrough SL, Thomas DSG, Shaw PA, et al. (2007) Multiphase Quaternary highstands at Lake Ngami, Kalahari, northern Botswana. Palaeogeography, Palaeoclimatology, Palaeoecology 253: 280-299.

Burrough SL and Willis KJ (2015) Ecosystem resilience to late-Holocene climate change in the Upper Zambezi Valley. The Holocene 25: 1811-1828.

Clark JD (1969). World Prehistory: A New Synthesis. Cambridge: Cambridge University Press.

Clark JD (2001). Kalambo Falls Prehistoric Site, Volume III. Cambridge: Cambridge University Press.

Clark, JD (1950). The Stone Age Cultures of Northern Rhodesia. Claremont: South African Archaeological Society.

Cohen AS, Stone JR, Beuning KRM, et al. (2007) Ecological consequences of early Late Pleistocene megadroughts in tropical Africa. Proceedings of the National Academy of Sciences of the United States of America 104: 16422-16427.

Collins JA, Schefuß E, Govin A, et al. (2014) Insolation and glacial-interglacial control on southwestern African hydroclimate over the past 140000 years. Earth and Planetary Science Letters 398: 1-10. 
643 Cornelissen E (2013). Hunting and gathering in Africa's tropical forests at the end of the Pleistocene 644 and in the early Holocene. In: Mitchell P and Lane P (eds): The Oxford Handbook of African

645 Archaeology. Oxford: Oxford University Press, 403-417.

646 Fagan, BM and Van Noten, F (1971). The Hunter-Gatherers of Gwisho. Musée Royal de l'Afrique

647 Centrale, Tervuren. Séries in- $8^{\circ}$, no. 74.

648 Fanshawe DB (1971) The vegetation of Zambia. Lusaka: Ministry of Rural Development. Forest 649 Research Bulletin 7.

650 Feathers JK (1997) Luminescence dating of sediment samples from White Paintings Rockshelter, 651 Botswana. Quaternary Science Reviews 16: 321-331.

652 Gabel, C (1965). Stone Age Hunters of the Kafue: The Gwisho A Site. Boston University African 653 Research Studies, no. 6.

654 Galbraith RF, Roberts RG, Laslett GM, et al. (1999) Optical dating of single and multiple grains of 655 quartz from Jinmium rock shelter, northern Australia: Part I, experimental design and statistical 656 models. Archaeometry 41: 339-364.

657 Haddon IG (2005) The sub-Kalahari geology and tectonic evolution of the Kalahari Basin, southern 658 Africa. The Sub-Kalahari Geology and Tectonic Evolution of the Kalahari Basin, Southern Africa: 343.

659 Haddon IG (1999) Isopach Map of the Kalahari Group. Council for Geoscience Pretoria, South Africa.

660 Inskeep RR (1959) A late Stone Age camping-site int he Upper Zambezi Valley. South African

661 Archaeological Bulletin 14: 91-96.

662 Ivester AH, Brook GA, Robbins LH, et al. (2010) A sedimentary record of environmental change at 663 Tsodilo Hills White Paintings Rock Shelter, Northwest Kalahari Desert, Botswana. Palaeoecology of 664 Africa 30: 53-78.

665 Kreutzer S, Dietze, M, Burow C, Fuchs MC, Schmidt C, Fischer M, Friedrich, J (2017). Luminescence: 666 Comprehensive Luminescence Dating Data Analysis. R package version 0.7.5. https://CRAN.R667 project.org/package=Luminescence

668 Kreutzer S, Schmidt C, Fuchs MC, Dietze M, Fischer M, Fuchs M (2012). "Introducing an R package for 669 luminescence dating analysis." Ancient TL, 30, pp. 1-8.

670 McCall, GS (2007) Behavioral ecological models of lithic technological change during the later Middle 671 Stone Age of South Africa. Journal of Archaeological Science 34 (10), 1738-1751.

672 Mejdahl V (1979). Thermoluminescence dating: Beta-dose attenuation in quartz grains.

673 Archaeometry 21: 61-72.

674 Mitchell PJ (2002). The Archaeology of Southern Africa, Cambridge and Cape Town: Cambridge

675 University Press. 
676 Moernaut J, Verschuren D, Charlet F, et al. (2010). The seismic-stratigraphic record of lake-level

677 fluctuations in Lake Challa: Hydrological stability and change in equatorial East Africa over the last

678140 kyr. Earth and Planetary Science Letters 290: 214-223.

679 Money NJ (1972). An outline of the geology of western Zambia. . Records of the Geological Survey, 680 Republic of Zambia. Republic of Zambia, 103-123.

681 Musonda, FB (1984). Late Pleistocene and Holocene microlithic industries from the Lunsemfwa

682 Basin, Zambia. The South African Archaeological Bulletin 39:24-36. Kreut

683 Partridge TC, deMenocal PB, Lorentz SA, et al. (1997) Orbital forcing of climate over South Africa: a

684200,000 -year rainfall record from the Pretoria Saltpan. Quaternary Science Reviews 16: 1125-1133.

685

Phillipson, L (1970) Excavations at Kandanda and Donke, Archaeologia Zambiana, Vol.12

686 Phillipson L (1975a) Survey of the Pleistocene and Holocene archaeology of the Upper Zambezi

687 Valley, Zambia. University of California at Berkeley.

688 Phillipson L (1975b) Survey of the Stone Age archaeology of the Upper Zambezi Valley: III. The

689 northern part of the valley. Azania 10: 1-48.

690 Phillipson L (1977) Survey of the Stone Age Archaeology of the Upper Zambezi Valley: III. The

691 Southern Part of the Valley. Azania 12: 83-110.

692 Phillipson D (1976). The Prehistory of Eastern Zambia. Nairobi: British Institute in Eastern Africa.

693 Robbins LH, Murphy ML, Brook GA, et al. (2000) Archaeology, palaeoenvironment, and chronology of 694 the Tsodilo Hills White Paintings Rock Shelter, northwest Kalahari Desert, Botswana. Journal of 695 Archaeological Science 27: 1085-1113.

696 Robbins LH, Brook GA, Murphy ML, Ivester AH, Campbell AC (2016). The Kalahari During MIS 6-2 697 (190-12 ka): Archaeology, Paleoenvironment, and Population Dynamics. In: Jones S, Stewart B (eds) 698 Africa from MIS 6-2. Springer, Dordrecht Vertebrate Paleobiology and Paleoanthropology, 175-193.

699 Roberts RG, Galbraith RF, Yoshida H, et al. (2000) Distinguishing dose populations in sediment 700 mixtures: A test of single-grain optical dating procedures using mixtures of laboratory-dosed quartz.

701 Radiation Measurements. 459-465.

702 Russell, NJ, Armitage, SJ (2012). A comparison of single-grain and small aliquot dating of fine sand

703 from Cyrenaica, northern Libya, Quaternary Geochronology 10, 62-67.

704 Savage, DK (1983). Identifying industries in South Central Africa: The Zambian Wilton example.

705 Unpublished PhD thesis, University of California, Berkeley.

706 Schefuß E, Kuhlmann H, Mollenhauer G, et al. (2011) Forcing of wet phases in southeast Africa over 707 the past 17,000 years. Nature 480: 509-512.

708 Schefuß E, Schouten S and Schneider RR (2005) Climatic controls on central African hydrology during 709 the past 20,000 years. Nature 437: 1003-1006. 
Scholz CA, Johnson TC, Cohen AS, et al. (2007) East African megadroughts between 135 and 75 thousand years ago and bearing on early-modern human origins. Proceedings of the National Academy of Sciences of the United States of America 104: 16416-16421.

Sealy J (2016). Cultural Change, Demography, and the Archaeology of the Last 100 kyr in Southern Africa. In: Jones S and Stewart B (eds), Africa from MIS 6-2. Population Dynamics and Paleoenvironments. Springer Dordrecht: Vertebrate Paleobiology and Paleoanthropology, 65-75.

Singarayer JS and Burrough SL (2015) Interhemispheric dynamics of the African rainbelt during the late Quaternary. Quaternary Science Reviews 124: 48-67.

Staurset S and Coulson S (2014) Sub-surface movement of stone artefacts at white Paintings Shelter, Tsodilo Hills, Botswana: implictaions for the Middle stone age Chronology of central southern Africa. Journal of Human Evolution 75: 153-165.

Stewart BA, Dewar GI, Morley MW, et al. (2012) Afromontane foragers of the Late Pleistocene: Site formation, chronology and occupational pulsing at Melikane Rockshelter, Lesotho. Quaternary International 270: 40-60.

Taylor N (2016). Across Rainforests and Woodlands: A Systematic Reappraisal of the Lupemban Middle Stone Age in Central Africa. In: Jones S., Stewart B. (eds) Africa from MIS 6-2. Springer, Dordrecht: Vertebrate Paleobiology and Paleoanthropology, 273-299.

Thomas DSG 1988 The nature and depositional setting of arid and semi-arid Kalahari sediments, southern Africa. Journal of Arid Environments 14: 17-26.

Thomas, DSG, Shaw, PA (1991). The Kalahari environment, Cambridge University Press, Cambridge.

Thomas DSG, Bailey R, Shaw PA, et al. (2009) Late Quaternary highstands at Lake Chilwa, Malawi: Frequency, timing and possible forcing mechanisms in the last 44 ka. Quaternary Science Reviews 28: 526-539.

Thomas DSG, Brook G, Shaw P, et al. (2003) Late Pleistocene wetting and drying in the NW Kalahari: An integrated study from the Tsodilo Hills, Botswana. Quaternary International. 53-67.

Thomas DSG and Burrough SL (2012) Interpreting geoproxies of late Quaternary climate change in African drylands: Implications for understanding environmental change and early human behaviour. Quaternary International 253: 5-17.

Thomas, DSG, Burrough, SL, Parker AG, (2012) Extreme events as drivers of early human behaviour in Africa? The case for variability, not catastrophic drought. Journal of Quaternary Science 27: 7-12. Thomas, DSG, Burrough, SL (2013). Luminescence-based dune chronologies in southern Africa: Analysis and interpretation of dune database records across the subcontinent, Quaternary International.

Tierney JE, Russell JM, Huang Y, et al. (2008) Northern hemisphere controls on tropical southeast African climate during the past 60,000 years. Science 322: 252-255. 
745 Vandenberghe D, De Corte F, Buylaert JP, et al. (2008) On the internal radioactivity in quartz.

746 Radiation Measurements 43: 771-775.

747 Van Riet Lowe, C (1935). Implementiferous gravels of the Vaal River at Riverview Estates, Nature $748 \quad 136,53-56$.

749 Villa, P, Soriano, S, Tsanova, T, Degano, I, Higham, TFG, D'Errico, F, Backwell, L, Lucejko, JJ,

750 Colombini, MP, Beaumont, PB, (2012). Border Cave and the beginning of the Later Stone Age in

751 South Africa, Proceedings of the National Academy of Sciences of the United States of America 109,

752 13208-13213.

753 Vogelsang, R, Richter, J, Jacobs, Z, Eichhorn, B, Linseele, V, \& Roberts, R (2010). New Excavations of

754 Middle Stone Age Deposits at Apollo 11 Rockshelter, Namibia: Stratigraphy, Archaeology,

755 Chronology and Past Environments. Journal of African Archaeology, 8(2), 185-218.

756 Wadley, L, (2015). Those marvellous millennia: The Middle Stone Age of Southern Africa, Azania 50, $757 \quad 155-226$.

758 Wang $Y V$, Larsen $T$, Leduc $G$, et al. (2013) What does leaf wax $\delta D$ from a mixed C3/C4 vegetation 759 region tell us? Geochimica et Cosmochimica Acta 111: 128-139.

760 Wintle AG, Murray, AS (2006) A review of optically stimulated luminescence characteristic and their 761 relevance in single-aliquot regeneration dating protocols. Radiation Measurements 41(4):369-391. 